\title{
The use of quartz during the Upper Paleolithic and Early Mesolithic in Sabor valley (NW Iberia): The Foz do Medal case
}

\author{
Rita Gaspar a, b, *, João Ferreira ' , Joana Carrondo b', Maria João Silva b \\ a InBIO - Rede de Investigação em Biodiversidade e Biologia Evolutiva, Laboratório Associado/ CIBIO - Centro de Investigação em Biodiversidade e Recursos \\ Genéticos, Universidade do Porto, Rua da Bataria, 174, 1ํ, 4000-104 Porto, Portugal \\ b Baixo Sabor-ACE, Portugal
}

\section{A R T I C L E I N F O}

\section{Article history:}

Available online xxx

\section{Keywords:}

Quartz

Rock crystal

Lithic industry

Upper Paleolithic

Early Mesolithic

\begin{abstract}
A B S T R A C T
The use of quartz is well documented during prehistory, being the predominant raw material in the Upper Paleolithic sites located in NW Iberia. The prehistoric occupations from Sabor valley also present a preference for this lithology through the long occupation sequence, although a large range of regional and exogenous lithic raw materials are also knapped.

Within the quartz varieties rock crystal seems to have an important role in some chronologies, especially since the Solutrean phase, regarding elongated products and small flake production. Several reduction strategies were applied to rock crystal although the unifacial exploitation from a $45^{\circ}$ degree striking platform using the crystal natural edges as guidelines is the most common. Though there are some similarities within the use of this type of cores throughout the chronological sequence we can observe some differences, especially during the Early Mesolithic phase.

In a regional perspective, it is possible to compare the quartz economy from occupations in Sabor valley to the ones from Côa valley, to the south, and discuss the role of rock crystal in Late Pleistocene inland human groups. It is clear that there was a technical ability to maximize a local lithic resource such as rock crystal which was exploited in order to achieve blanks similar to those obtained from flint cores. (C) 2015 Elsevier Ltd and INQUA. All rights reserved.
\end{abstract}

\section{Introduction}

The long occupation sequence of Foz do Medal makes it a crucial site to understand Late Pleistocene and Early Holocene human communities in Northwest Iberia. Among the lithic assemblage, quartz is in clear evidence, being the most common raw material in knapped stone assemblages. This dominance is common to the prehistorical sites from this Iberian region, particularly in the nearby Côa valley region.

The extended raw material studies that have been made in Côa valley (Aubry, 2009; Aubry et al., 2012) allowed great increase in data regarding the raw material management strategies from inner Iberia Upper Paleolithic human groups, especially in the case of exogenous rocks. This data can now be enhanced with the recent

\footnotetext{
* Corresponding author. InBIO - Rede de Investigação em Biodiversidade e Biologia Evolutiva, Laboratório Associado/ CIBIO - Centro de Investigação em Biodiversidade e Recursos Genéticos, Universidade do Porto, Rua da Bataria, 174, $1^{\circ}$, 4000-104 Porto, Portugal.

E-mail address: ritantunesgaspar@gmail.com (R. Gaspar).
}

studies in Sabor valley and its contribute to the understanding of local raw material management strategies. The use of several quartz varieties is complemented in Sabor valley with a large range of local and regional rocks such as hydrothermal silicifications, opal, jaspers, lydite, rhyolite and mafic granulite among others, which had an important role in these groups economy.

In this paper, the use of the different quartz varieties in general and especially rock crystal is presented in a diachronic perspective, through an exceptional stratigraphic sequence in the region, covering a period between the Early Upper Paleolithic and the Early Mesolithic. This site presents a unique opportunity to analyze the selection and use of these raw materials especially regarding the production of bladelets and small flakes.

\section{Regional setting}

Foz do Medal is located at the confluence of Medal stream with Sabor river (WGS84: $41^{\circ} 15^{\prime} 15.49^{\prime \prime} \mathrm{N}$ and $6^{\circ} 53^{\prime} 01.72^{\prime \prime} \mathrm{W}$ ), in a low fluvial terrace, $9 \mathrm{~m}$ above the river level and $165 \mathrm{~m}$ above sea level. The Sabor River is located in Trás-os-Montes region (Northeastern Portugal) (Fig. 1) and, like the Côa River situated to the south, it is 


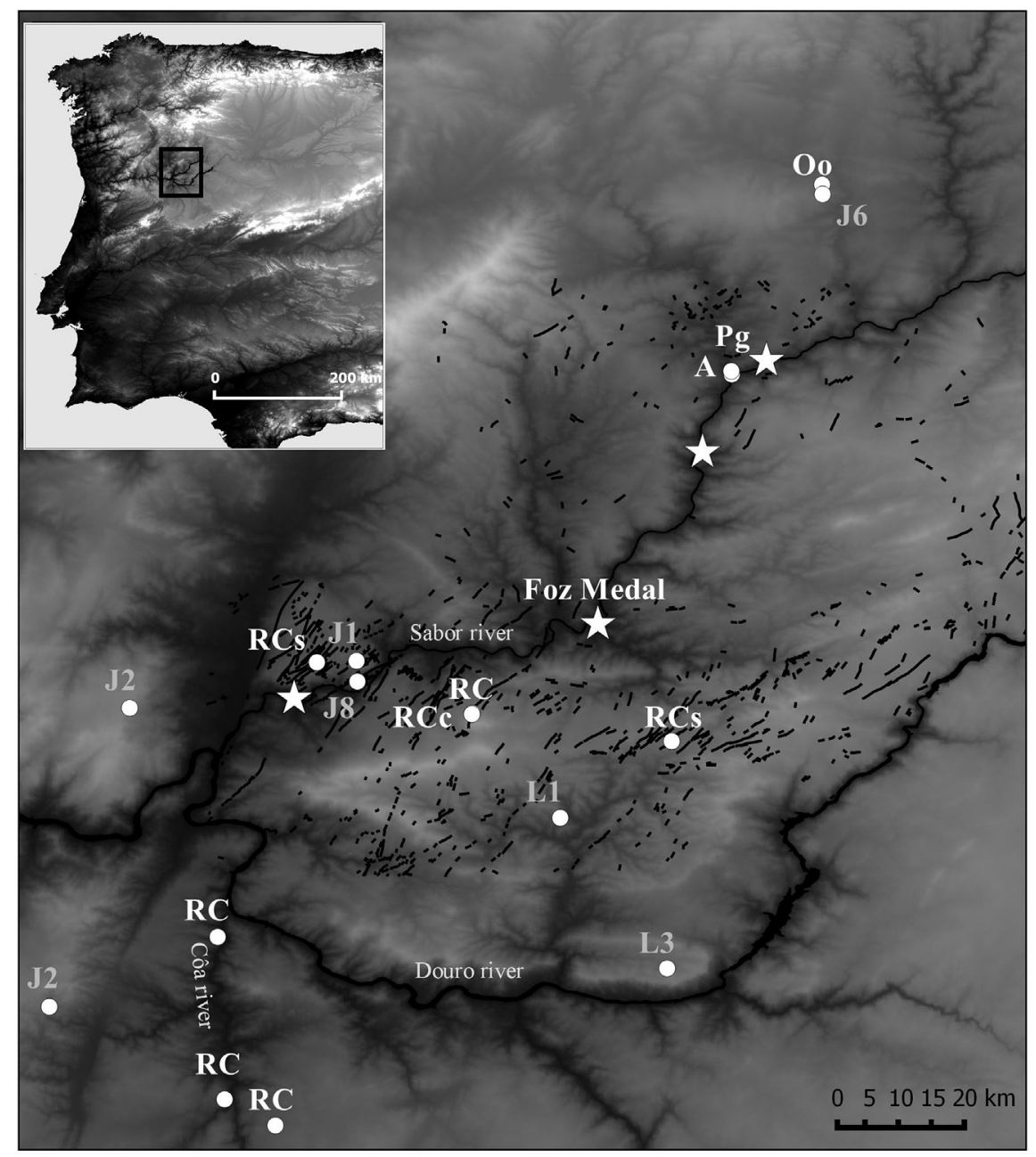

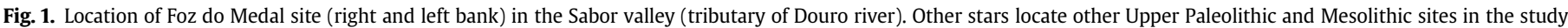

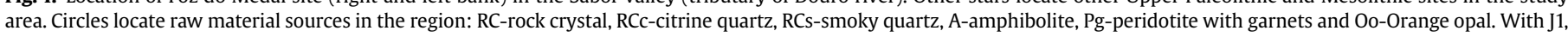
J2, J6, J8, L1 and L3 several silicifications according to Aubry et al. (2014). The local quartz veins are in black.

one of the most important tributaries of the Douro basin. The entire region, located in a marginal area of the high plains of central Spain, has suffered intense erosion that led to the creation of deep valleys with a very irregular topography. It is quite common to find differences of $800 \mathrm{~m}$ between the bottom and the top of the Sabor valley (Silva et al., 1989).

The Sabor is a narrow bed river with high-gradient slopes in most of its course. It runs mainly from the northeast to southwest, geographically between the Gamoneda mountain (Zamora, Spain) and the Vilariça valley (geomorphic expression of ManteigasVilariça-Bragança fault that limited North Meseta to the west). The region has suffered intense deformation related with both the Morais Massif intrusion of allochthon continental and oceanic plates and tectonic activity due to Manteigas-Vilariça-Bragança fault, since the Variscan orogenesis (Cabral, 1995). The fault activity from Upper Pliocene to Quaternary is considerable, resulting in about $1 \mathrm{~km}$ of displacement (Perea et al., 2010). Recent studies have identified at least two earthquakes between 14.5 and $11 \mathrm{ka}$ (Rockwell et al., 2009).

As the result of intense deformation, this region presents a large variety of metamorphic lithologies along with the granitic formations typical of the Variscan basement of the Iberian Peninsula (Silva et al., 1989). The Sabor river course cuts both metamorphic and igneous bedrock.
All these factors contribute to the rich context concerning raw material variety. Although no biogenic sedimentary siliceous rocks exist in the region, there are some hydrothermal silicifications such as volcanic opal (Aubry and Mangado, 2006), jasper or other local varieties. The high tectonic activity led to numerous quartz vein exudations (Fig. 1). The intense drainage and erosion in the region, together with existing thin soils, expose potential raw material sources. The large varieties of high or medium siliceous content rocks, with fine-grained textures (other than the exogenous biogenic flint) are reflected in the prehistoric lithic assemblages, especially the ones from the Upper Paleolithic occupations.

\section{Material and methods}

\subsection{Occupation sequence}

Foz do Medal occupations are distributed by the two margins of the Medal stream (Fig. 2). The stratigraphic sequence is composed by several phases of alluvial accretion and erosion complemented with some slope deposition. Although three major alluvial deposition phases were identified, it is only in the last sedimentary phase that Upper Paleolithic occupations appear. Because the focus of this paper is the use of quartz as raw material during the 


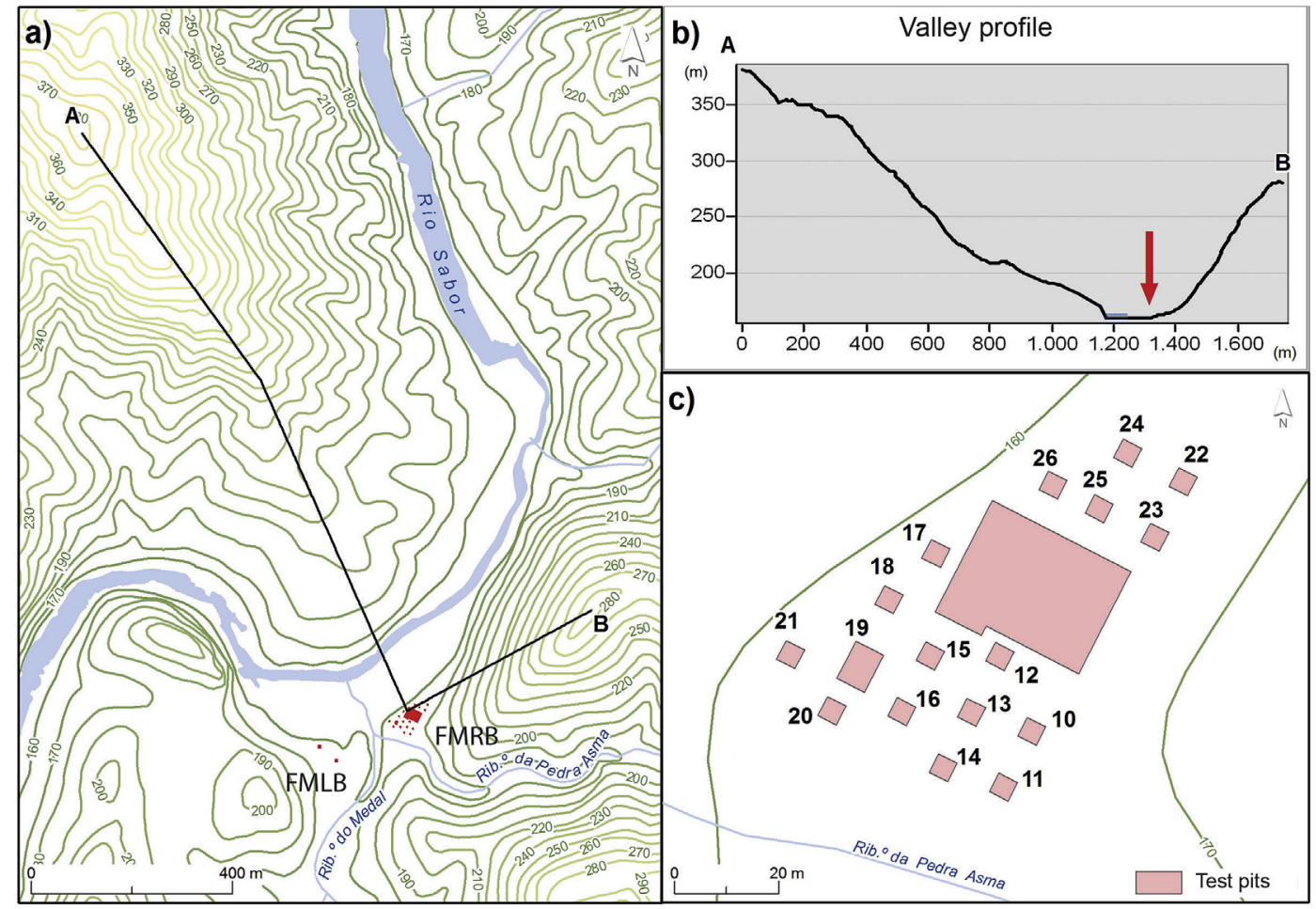

Fig. 2. Location of Foz do Medal (FMLB and FMRB) in the left bank of Sabor river (a); valley profile with FMRB location (b) and test pits in Foz do Medal Right Bank (c).

sequence, the stratigraphic sequence will be presented briefly (Fig. 3).

The first major alluvial deposition phase corresponds to channel bottom deposits from the period before the migration of the Sabor course to the opposite margin. The second major deposition phase corresponds to a sequence of massive thick fine-grained deposits. In this phase, some slope contributions are visible, interbedded with the alluvial deposits in the eastern area. The third major sedimentation phase is a thick finegrained sequence from waning floods. In this phase, the Sabor course was already in its current position which allowed dense and extensive human occupation of the platform. At the base, there is a succession of sand, silt, and mud with horizontal lamination. The first Upper Paleolithic remains (corresponding to Phase II of human occupation) stands on top of this sedimentary unit. A massive silt and sand thick deposit covers this wellpreserved occupation. The remains of the Gravettian occupation (Phase III) lay on top of these deposits, and are covered by another massive silt and sand alluvial deposit, on top of which rests the remains of the Magdalenian occupation (Phase IV). Both Gravettian and Magdalenian occupations are not in primary position. The layers with human occupation evidence are separated by alluvial deposits, representative of flood periods, and sometimes indications of slope erosion. The Early Mesolithic occupations are in the upper part of the alluvial sequence. From these phases, we observe different preservation conditions. Several structures and levels were detected. The last prehistoric occupation of the platform was during the Bronze Age (Gaspar et al., 2014) which disturbed some of the previous remains.

The fieldwork on the Right Bank of Foz do Medal was conducted from December 2011 to January 2013, and $884 \mathrm{~m}^{2}$ were excavated in total. Water screening used in the Paleolithic and Mesolithic levels led to the identification of lithic pieces smaller than $5 \mathrm{~mm}$.
The total lithic collection from the site includes over 200000 pieces, resulting from the six major human occupation phases. The works on Left Bank were carried out between 2012 and 2013, and $16 \mathrm{~m}^{2}$ were excavated.

The lithic collection from the site resulted from seven major human occupation phases, six in the Right Bank (RB) and one (the Solutrean) in the Left Bank (LB):

Ancient Paleolithic (Phase I from RB). This level will not be included in this study.

The Early Upper Paleolithic occupation (Phase II from RB) was identified only on a small area of the platform, about $2 \mathrm{~m}$ below the surface, occupying approximately $35 \mathrm{~m}^{2}$. The occupation remains are very well preserved and two hearths were identified. The presentation of this data is still under preparation. A lithic assemblage of 893 pieces, with 828 knapped stone elements, was recovered in association with the structures. Densities of 170 lithic pieces were recorded in some square meters. No faunal remains were recovered. Regarding the raw materials management, quartzes are clearly dominant and, in contrast to the other Upper Pleistocene phases, the range of raw materials selected by this group if clearly inferior, regardless of the large range of siliceous raw materials available in the territory. The reduction strategies were directed to flake production, with a preference for large elongated flakes. The larger flakes are produced in quartzite, greywacke and lydite while the smaller ones in quartz. The milky quartz, cherts and hydrothermal silicifications were selected for the bladelets and the rhyolite, milky quartz and fine grained quartz for the blades. Both products are almost residual in the assemblage. The strategies used are generally simple and expeditious with little core preparation or management, although more careful reductions like prismatic cores, carinated "endscraper" and carinated "burin" are also present. For those reductions, milky quartz, fine grained quartz and rock crystal were selected. For tool production, quartz, quartzite, hydrothermal 


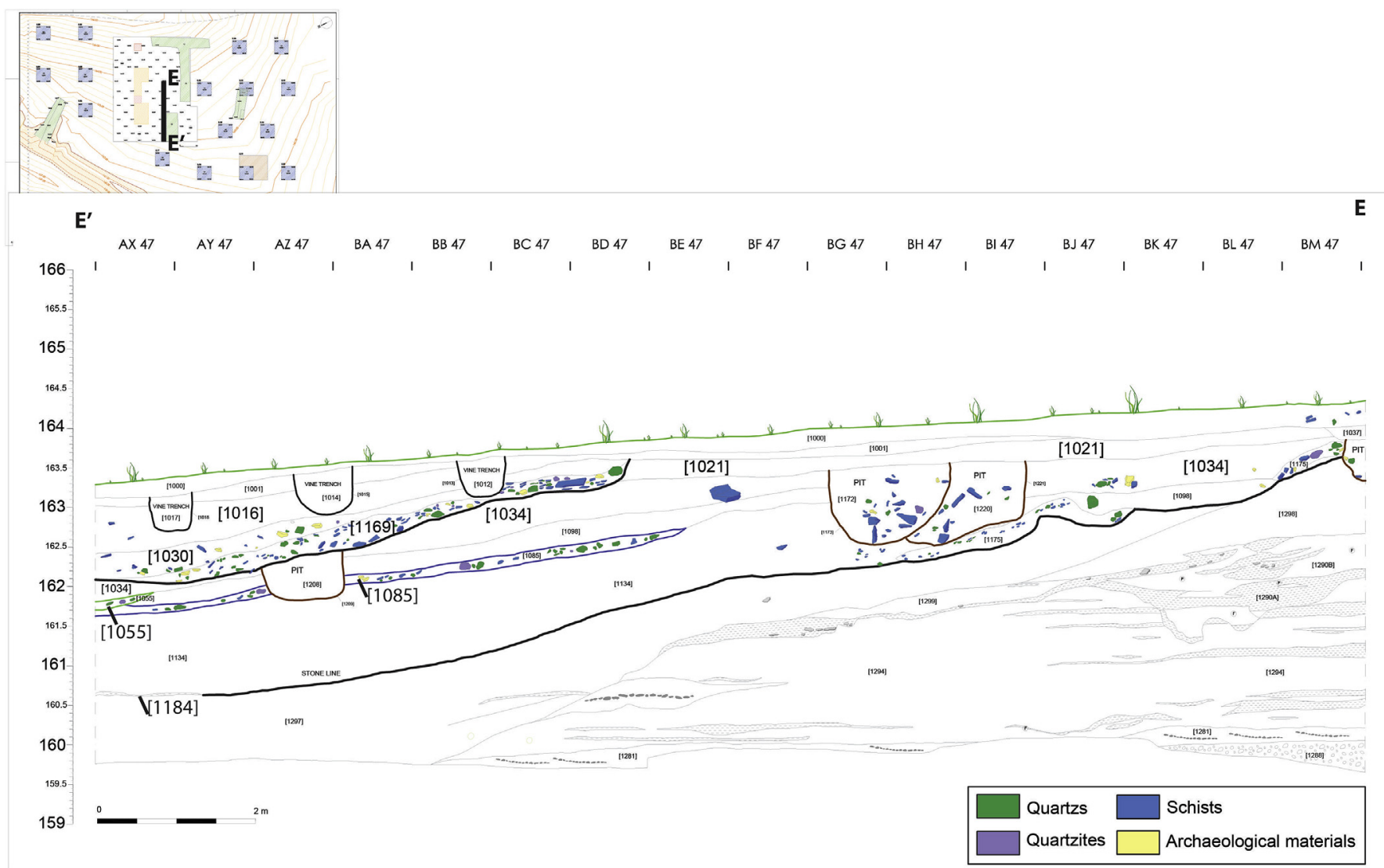

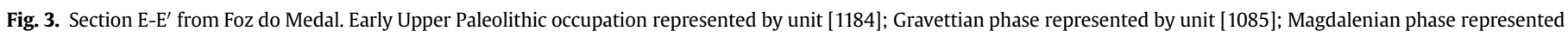
by unit [1055] and Early Mesolithic phase represented by the pits opened in unit [1034].

silicifications and greywacke were the preferred raw materials. Within the toll assemblage, retouched elements such as flakes, fragments, and blade dominate. An end-scraper, notches and denticulates on flake were also recovered. No points or other typical Gravettian elements were found.

The Gravettian occupation (Phase III from the Right Bank) is materialized in deposit [1085] and base levels from [1098]. The extension of the first deposit is about $280 \mathrm{~m}^{2}$. No preserved structures were identified although a large amount of pieces showing thermal exposure was collected. The large lithic assemblage, 56363 pieces, of which 52071 correspond to a knapped stone assemblage, indicates the presence of a major Gravettian occupation (Gaspar et al., accepted a). 1500 lithic pieces were recorded in some square meters. Quartz clearly dominates the assemblage. The production is mostly oriented to obtain flakes spanning from 1 to $3 \mathrm{~cm}$ wide. The strategies used are generally simple and expeditious with little core preparation or management. Elongated products are less than $1 \%$ of the debitage and were produced through more careful methods. Prismatic cores, bipolar on anvil cores and splintered cores, carinated "end-scraper" core, core-"burin" and unipolar on crystal morphology cores were used for bladelet production. The authors of this paper decided to distinguish two categories of cores showing bipolar technique. Bipolar on anvil cores were prepared and managed to produce bladelets through bipolar technique, as described for Cardina 1 by Klaric et al. (2009), which may or may not result in impact marks on the extremities of the core. Splintered cores produced mainly small flakes and chips but also bladelets, causing the splintering of the extremities. No cores for blades were identified although there are blades in the assemblage. Some were clearly introduced from the exterior, as the raw material in which they are made is unique and thus cannot be related with any on-site knapping activity. The assemblage shows a very small percentage of core maintenance products, mainly on chert or fine grained siliceous rocks. The core maintenance was almost only applied in reduction sequences producing elongated and thin products on exogenous lithologies. As shown in other Gravettian assemblages in Portugal (Zilhão, 1997; Almeida, 2000), in Foz do Medal small thin flakes and chips were intentionally produced to be used as barbs without retouch. This is confirmed by the presence of "splintered piece" cores, but mostly by blocks of quartz which were knapped either by unipolar technique or bipolar technique using anvils.

Among the small tool assemblage, where retouched elements dominate, there are notches, denticulates, side-scrapers, splintered pieces and one pick. Within the "domestic tools", the endscrapers, burins, retouched blades and blade fragments, worked pebbles or chopper/chopping-tools composite tools, one backed blade fragment (knife), one double-truncated blade, and one perforator. Among the projectile points there is one atypical or unfinished La Gravette point and one possible, though doubtful, Vale Comprido point. For the tools on bladelets, which were probably projectile elements, only cherts, rock crystal milky quartz and lydite were selected. This assemblage comprehends backed bladelets, double backed bladelets, one microgravette, marginally retouched bladelets, and some irregular/unfinished marginally retouched bladelets. 
The Solutrean occupation (the only one identified in the Left Bank) has suffered a small displacement. Only $16 \mathrm{~m}^{2}$ were excavated and the remains of the occupation were identified in layers [413] and [414] (Gaspar et al., accepted b). No preserved structures were identified although several quartzite and greywacke cobbles with evidence of thermal alteration were collected. A total of 830 artefacts were recovered (782 of which are knapped stone). Some refittings among the knapped stone assemblage were accomplished.

Although quartzite (42.1\%) and quartz (43.3\%) were the most used raw materials, exogenous siliceous raw materials are also present. Similar proportions of quartz and quartzite do not exist in the other occupations at Foz do Medal, where quartz clearly dominates. The reduction sequences directed to the production of large flakes through simple strategies dominate the assemblage, although a range of more careful strategies were also identified. These ones are applied mainly on cherts, hydrothermal siliceous rocks, rock crystal, and milky quartz for the production of small flakes, chips and bladelets. Those are also the raw material selected for tool production, mostly using flakes as a blank, such as retouched flakes, endscrapers, dihedral burins, notches, denticulated flakes, and borers. The only tools using elongated blanks are one truncated bladelet and one fragment of a retouched blade. We must emphasize the presence of one proximal fragment of a Solutrean laurel leaf, on milky quartz (Gaspar et al., accepted b). Other indicators of bifacial retouching were found, such as several thin flakes, prepared by abrasion or faceting butts. These flakes are on local hydrothermal siliceous rocks, carbonated chert and lydite. Besides these elements linked to leaf point technology, there are others displaying characteristic plain invasive retouch. Alongside with the production of bifacial elements we have recorded the presence of a macrolithic component in quartzite. There is a selection of elongated, flat pebbles (quartzite and quartz) for producing heavy-duty tools such as pick-axes and unifacially worked pebbles.

The Magdalenian occupation (Phase IV from the RB) was detected in layer [1055] and equivalents [12001], [17004] e [26002]. This deposit is the result of the erosion of the original occupation and shows some post-deposition alterations. Some materials were found in the bottom levels of layer [1034] that covers [1055]. Remains of this phase cover $190 \mathrm{~m} 2$, although due to the excavation of several test pits we estimate a total area of $520 \mathrm{~m}^{2} .166929$ lithic pieces were collected, 159482 resulting from stone knapping. Some square meters present a density of 3700 lithic pieces. No structures were identified although a large number of thermal-altered blocks and pebbles indicate that hearths would have existed in the area. The presence of large greywacke slabs suggest that space was structured in some way.

In this occupation, 1250 greywacke slab fragments with engravings representing abstract and zoomorphic figures were collected (Figueiredo et al., 2014). Among the zoomorphic figures, the caprids are the most common. This can also be observed in the Cantabrian Magdalenian, where the number of representations of these animals increases (Figueiredo et al., 2015). This assemblage is the largest mobile rock art collection from an open-air Paleolithic site in the Iberian Peninsula.

Regarding the raw material management, this phase presents the larger range of lithologies, reflecting not just the richness of the surrounding but also the excellent knowledge of the territory by this group and the capacity to explore these resources and to knapp such lithologies. The present of exogenous materials also increases in this phase. Quartz varieties are dominant. Small flakes (with length between 1.5 and $2 \mathrm{~cm}$ ) are the most common blanks being milky quartz, translucent quartz and cherts the preferred raw materials. Bladelets increase their presence during the Magdalenian. The raw materials selected are cherts, milky quartz, and rock crystal. The strategies observed in the core assemblage are generally simple and expeditious with little core preparation or management for flake production. For elongated blanks, we can observe the presence of prismatic cores, splintered cores, bipolar on anvil, carinated "end-scraper" core, core-"burin" and unipolar on crystal morphology cores, preferably on cherts, milky quartz, rock crystal and translucent quartz. These cores are generally found at an advanced state of exploitation. Retouched pieces on small flakes, bladelets and blades dominate the tool assemblage. There is also a significant presence of denticulates, notches, and burins. A large variety of end-scrapers was observed with the presence of thumbnail end-scrapers and scrapers on flake. Regarding barbs, backed bladelets and double backed bladelets dominate.

The Early Mesolithic occupations (Phase V from the RB) are relatively well preserved. The presentation of this data is still under preparation. This phase includes two levels (Phases Va and $\mathrm{Vb}$ ) with several structures, such as hearths, pit-holes and other negative structures. 1758 lithic pieces, 1079 knapped stones, were collected. During Early Mesolithic the use of quartz surpasses $90 \%$, and the siliceous exogenous raw materials are almost absent. The strategies applied aim for the production of flakes. Milky quartz, translucent quartz and rock crystal are selected for small flake production. Less apt quartz and quartzite are applied in flakes larger than $2.5 \mathrm{~cm}$. Bladelets are residual and blades absent. In this phase, the dominant reduction methods are the prismatic, bipolar on anvil and unipolar on crystal morphology cores, preferably on milky quartz, translucent quartz, rock crystal and smoky quartz. Notches are clearly the most represented tools in the assemblage. Retouched pieces and denticulates are also well represented. We notice the presence of pick-axes and bifacially worked pebbles. In Phase Va we have also found one end-scraper and one backed bladelet. Tools are almost exclusively produced on milky quartz, rock crystal and smoky quartz. The residual microlithic component and the significant presence of notches and denticulates show similarities with the Mesolithic from the Ebro basin described by Alday (2006).

\subsection{Raw materials}

Dozens of different raw materials were selected by prehistoric groups either for knapping or other activities. Such diversity led to the creation of a reference collection of regional raw materials. The raw materials in the lithic assemblage were macroscopically sorted by categories and identified with the help of José Feliciano, University of Oporto. Geological research for the region and the raw material procurement studies made by Côa Valley Archaeological Park investigation team since the 1990s (Aubry et al., 2004; Aubry, 2009) were also consulted. This task is still ongoing, due to the enormous regional variety and the chemical alteration of some rocks that complicates petrographic identification.

During field work in the valley, it was possible to survey some potential areas and identify the sources of some of the rocks (Fig. 1). Some of the raw material located in Fig. 1 were identified by Côa Valley Archaeological Park investigation team and correspond manly to silicifications in vein (J1, J2 and J8), volcanic Opal (J6) and siliceous rock (L1 and L3) (Aubry et al., 2014).

Since the focus of this paper is on quartz use, especially the role of rock crystal, the other lithologies were aggregated in four large groups, each with a variety of sub-types, described next. The study of the complete raw material economy is still ongoing. Five lithological groups are considered:

1. Quartz varieties, ranging from excellent to low knapping qualities (Fig. 4). This group comprehends milky quartz (Fig. 4h), 

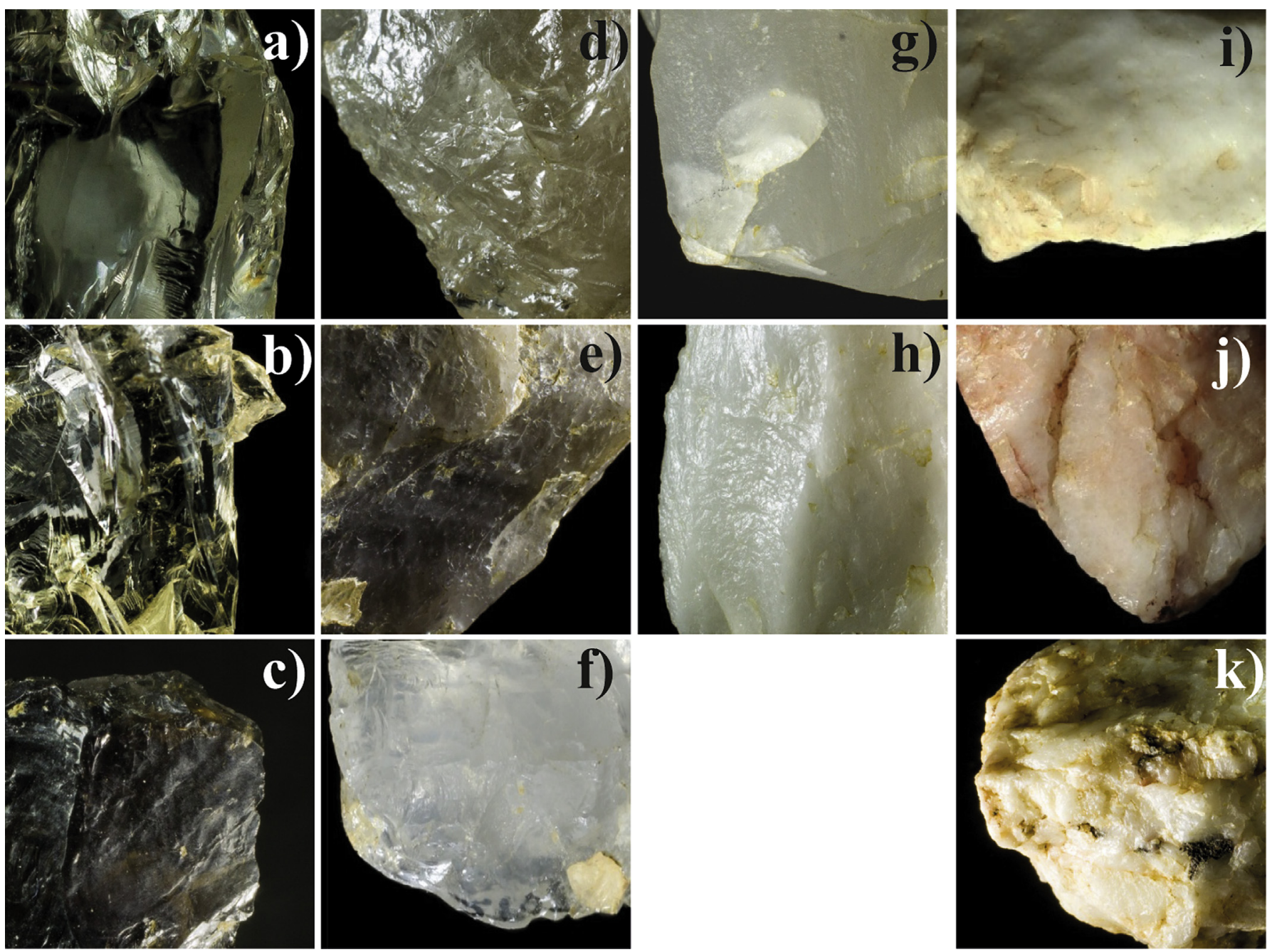

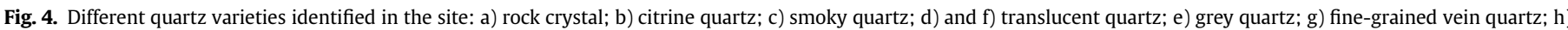
milky quartz; i), j) and k) other varieties of quartz with less knapping aptitude.

grey quartz (Fig. 4e), translucent quartz (Fig. 4d and 4f), fine vein quartz (Fig. 4g) (probably from Morais Massif formation), rock crystal (Fig. 4a), smoky quartz (Fig. 4c), citrine quartz (Fig. 4b) and some other quartz varieties with less knapping qualities (Fig. $4 \mathrm{i}, 4 \mathrm{j}$ and $4 \mathrm{k}$ ). The presence of several types of quartz locally has been mentioned by several authors (Silva et al., 1989; Aubry et al., 2014)

2. Quartzite, presenting several grain sizes and textures. Quartzites are available either in primary sources through Ordovician outcrops and secondary sources in gravel deposits in the Sabor basin (Silva et al., 1989; Aubry et al., 2014).

3. Cherts. This group includes various sub-types, from different geographical sources. As the focus of this work is quartz, the sub-types of non-local cherts will not be detailed.

4. Local siliceous rocks. This group includes other rocks with high percentage of silica and fine grain textures. It includes the local variety of volcanic opal, jaspers, hydrothermal silicifications, lydite, (identified by Aubry et al. (2004) and Aubry et al. (2014) in Northeast Portuguese raw material studies), rhyolite and mafic granulite.

5. Greywackes, serpentinites, amphibolites, peridotite, dacite, gneiss, sandstone, schist, among others. These lithologies are found in the knapped stone assemblage but are used mostly as components of structures, plaquettes for engraving rock art or anvils related with knapping or other domestic activities. These raw materials are available either in primary sources through outcrops and secondary sources in gravel deposits in the Sabor basin (Silva et al., 1989).

\section{Results}

Foz do Medal (both right and left banks) presents an important sequence covering the Upper Paleolithic and Early Mesolithic offering the unique opportunity to analyze the raw material economy throughout the Late Upper Pleistocene-Early Holocene, especially concerning quartz. Knapped stone assemblages from 5 phases of human occupation were selected.

In the Early Upper Paleolithic occupation, quartz represents $73.4 \%$ of the collection (Fig. 5). There is a clear selection of quartz varieties, as we can perceive from the large volumes of blank production. $67.9 \%$ of the cores are in quartz, especially in local varieties (milky quartz and other quartz varieties less fit for knapping). The strategies applied to the local quartz are generally expeditious and frequently use the volume's raw morphology (cobbles, slabs or flakes) for flake production, mainly through unifacial or unidirectional approaches but also bifacial reduction 


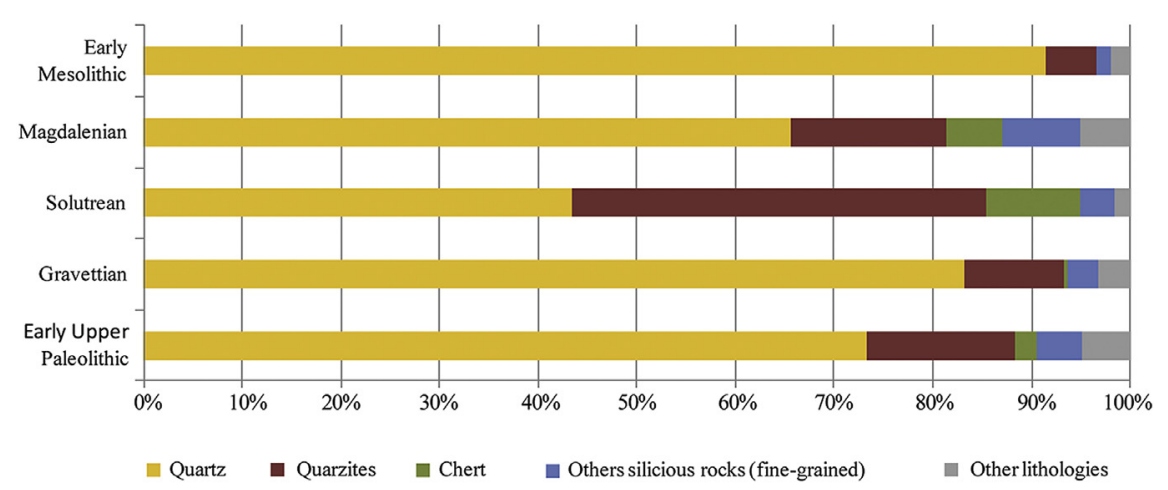

Fig. 5. Raw material groups present in the different Foz do Medal phases. Notice the dominance of quartz varieties in almost all the phases.

and strategies that result in a polyhedral final morphology, where the last detachment negative is used as a striking platform for the next blank removal. The prismatic cores, carinated "end-scraper" and bipolar on anvil cores are only found on milky quartz. The only core identified on rock crystal in this phase is one carinated "burin". No flint cores were identified, although some blanks (bladelets and small flakes), waste and maintenance products were recovered, which indicates flint knapping activity in the place. We can assume that these cores were carried by the human group. Quartzite only represents $15.1 \%$ of total assemblage. Regarding the tool assemblage, quartz is dominant (82.6\%). It includes retouched flakes and fragments in milky quartz and other local quartz, one retouched blade on fine-grained vein quartz and one end-scraper in milky quartz. Some quartzite flakes where also retouched and used as blanks for denticulates. No tools on chert were recovered.

Concerning the Gravettian assemblage, we observe an increase in the use of quartz (83.2\%) and a decrease in quartzite (10\%) and flint (no more than $0.5 \%$ ). However, only half of the cores is in quartz, and within the quartz group the local varieties prevail. In these local, less fit, quartz varieties we observe expeditious approaches similar to those described previously, with the difference that there are a broader range of this strategies intended to produce similar blanks (Gaspar et al., accepted a). There are a number of centripetal cores, tested cores with one or two removals and cores with no apparent strategy. However, having in mind the huge difference in size of the recovered assemblages, these variations are not statistically significant and cannot be considered as evidence of any profound change in human subsistence strategies. Reduction sequences applied to fine quartz, namely milky quartz and rock crystal, aim the production of small flakes and bladelets. Prismatic cores, bipolar on anvil cores and $45^{\circ}$ platform angle on crystal morphology cores are the preferred methods for obtaining these blanks. Similar products were obtained through carinated reduction strategies, but only seldom. Regarding the production of bladelets the rock crystal is clearly the main choice, although we can also find chert and milky quartz and in residual amounts jasper, hydrothermal silicification and lydite. Concerning the tool collection, retouched flakes (milky quartz, quartzite, rock crystal and other quartz) also prevail. The notches on milky quartz, quartzite and rock crystal are the second most abundant group. Chert and milky quartz were selected for the end-scrapers. Side-scrapers, burins and denticulates are also present. The barbs include backed and double backs bladelets. One Gravette point and one microgravette in rock crystal (Fig. 6.6) were also collected. Quartz seems to have been a clear choice for tool production alongside with chert.
In the Solutrean collection, quartz and quartzite appear in equal proportions ( $43.4 \%$ and $42.1 \%$ respectively) and chert $(9.5 \%)$ gains significant weight in the raw material economy (Fig. 5). Other lithologies are also present in smaller amounts. Only $25.4 \%$ of cores are in quartz varieties. This phase presents the lowest percentage of quartz cores in the site. The majority of the reduction sequences are directed to the production of large flakes through simple and expedite strategies (70\% of the cores), which seems to be directly related with the raw materials selected (Gaspar et al., accepted b). There is a production of small flakes, chips, and bladelets mainly on cherts, hydrothermal siliceous rocks, rock crystal, and milky quartz. Regarding the tool production chert, milky quartz, and jasper flakes were often used in the making of retouched flakes, end-scrapers, dihedral burins, notches, one denticulated flake and one borer. A truncated bladelet on rock crystal and a fragment of a retouched blade are the only exceptions among the tool blanks. A laurel leaf shaped on milky quartz (Fig. 6.9) demonstrates the knapping potential of quartz in the tool-making. It seems that quartz and rock crystal small blanks could have been used as non-retouched barbs, as happens in other sites (Gameiro, 2009). Other important feature of this assemblage is the presence of macrolithic components in quartzite (two pick-axes and one unifacially worked pebble were recovered) presenting visible use-wear traces.

The Magdalenian occupation is characterized by an increase in the use of quartz in all its varieties (65.6\%) together with an increase in the use of other siliceous fine-grained regional rocks (7.7\%), such as jasper, and lydite among others (Fig. 5). The quartzites total $15.8 \%$ of the collection, and chert $5.7 \%$. In the Magdalenian lithic assemblage, there is a larger variety of raw materials than in other stages of human occupations in the site indicating a different raw material economy. In general, the reduction strategies are orientated for small flake production using milky quartz, translucent quartz, rock crystal, and chert. The elongated blanks represent only $1.7 \%$ of the debitage products. Prismatic cores, splintered cores, bipolar on anvil cores, carinated "end-scrapers" cores and carinated "burins" for bladelet and small flake production are present. There is also a production of larger flakes in quartzite and less apt quartz through unifacial, bifacial and centripetal strategies.

Concerning tool collection, chert, milky quartz and quartzite are the predominant selection. Retouched elements dominate, especially on flakes. There are also denticulates, notches, burins and end-scrapers (including thumbnail end-scrapers). Backed knifes and borers on chert are also present. Backed bladelets, double backed bladelets and double backed points are the existing barbs. Quartzite is also applied on side-scrapers and choppers production. 


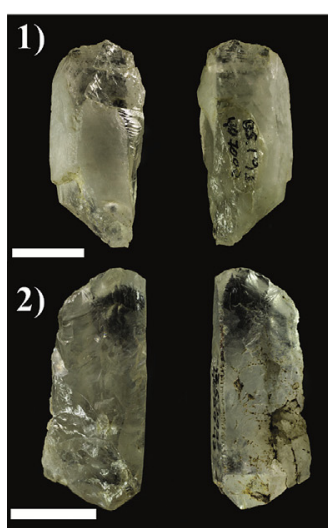

6)

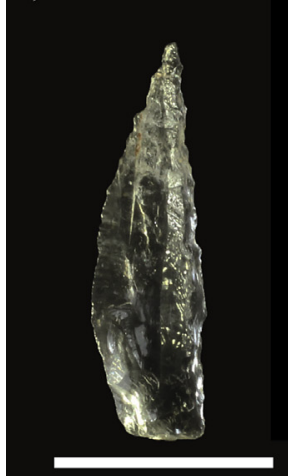

3)

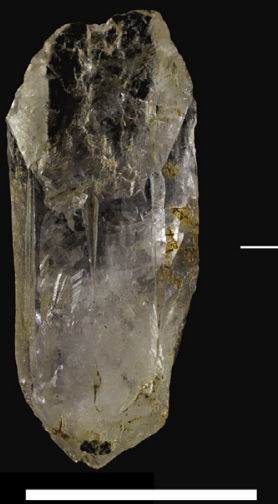

7)

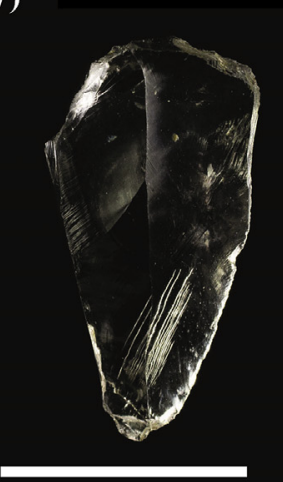

4)

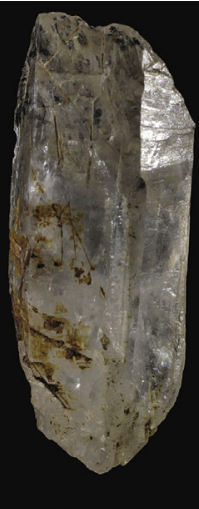

8)

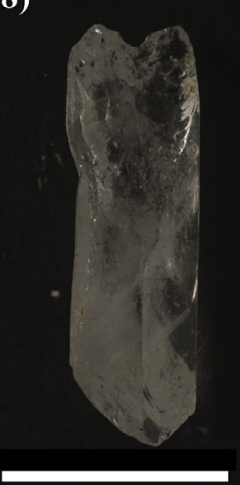

9)
5)
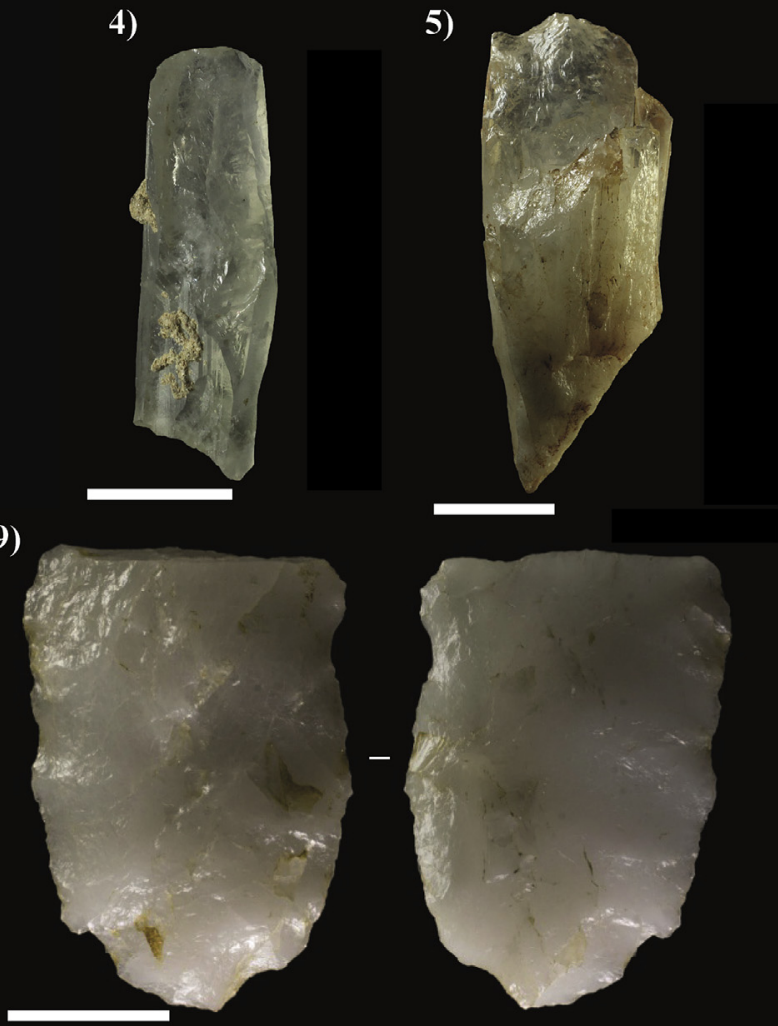

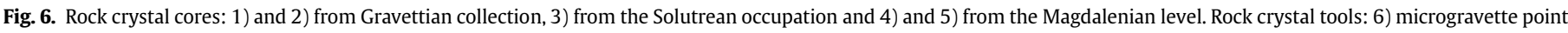

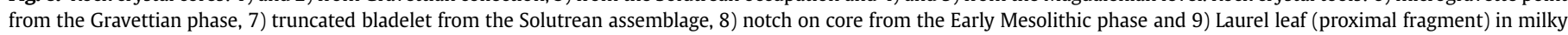
quartz from Solutrean phase (Photos by Andrew May and João Ferreira).

In the Early Mesolithic Phase, quartz use comprises 91.5\% of the knapped stone collection, while flint is present only in a residual way $(0.1 \%)$ (Fig. 5$)$. The increasing use of quartz is accompanied by the decrease of all the other groups of raw materials. Even quartzite represents only 5.1\%. The reduction strategies are oriented for flake production using milky quartz, rock crystal, and smoky quartz for production of smaller blanks, through splintered cores and bipolar on anvil cores. The larger flakes are obtained from quartz with less knapping aptitude, quartzites, and greywacke applying unifacial, polyhedric and centripetal type strategies. Prismatic cores and $45^{\circ}$ angle striking platform cores were also collected. These volumes were used to produce small flakes and bladelets.

The notches dominate the tool collection, for which better varieties of quartz were selected. Denticulates, end-scrapers, one borer, one burin and one backed bladelet were also collected. An interesting feature of this assemblage is the presence of macrolithic components like pick-axes and bifacial worked pebbles.

Unfortunately, there is no faunal or other organic remains associated with these lithic collections that can indicate what kind of activities occurred in the site during the different phases. The exception is the Early Mesolithic levels where several charcoal remains were collected and are under study. All the assemblages from the site show a large range of raw materials, with quartz the most represented in all of them.

\subsection{Selection of quartz}

Even in regions where biogenic flint sources are abundant, Portuguese Upper Paleolithic assemblages show an important component of non-flint raw materials (such as quartzite and quartz). For instance, during the transition from Gravettian to Solutrean in Rio Maior area (Portuguese Estremadura), one can observe an increase in quartz use in the lithic artifact collections. Quartz reaches $22 \%-43 \%$ of the total lithic assemblage, being the best varieties selected specially for bladelet production trough prismatic cores, burins and carinated "end-scrapers" (Zilhão et al., 1997).

An important feature in most Western Iberia prehistoric sites located far from the coastal Mesozoic sedimentary background and from the Cenozoic inner basins, thus with few or no biogenic flint sources, is the predominance of quartz, and in some cases quartzite, in lithic assemblages, which is observable in every chronology. The same thing can be said for Upper Paleolithic occupations in NW Iberia (Aubry and Araújo Igreja, 2009; Lombera Hermida and Rodríguez Rellán, 2010) and for Early Holocene assemblages from Portuguese inner south region (Gaspar et al., 2009). In these sites, a large variety of quartzes were used for different reduction strategies, according to quartz texture and knapping qualities. Quartz is also conspicuous in several European Upper Paleolithic sites (Bracco, 1998).

At Foz do Medal, we can observe a long sequence of human occupations where quartz is also clearly dominant within the knapped stone assemblages. Despite the fact that high fragmentation of quartz (Tallavaara et al., 2010; Driscoll, 2011) can lead to an overrepresentation of this raw material in the collections, the high percentages of quartz varieties in Foz do Medal (ranging from 43.4\% to $91.5 \%$ ) (Table 1 ) suggests that it reflects a human choice. This is especially clear in the case of rock crystal in some of the chronological stages. 
Table 1

Diachronic perspective of the use of quartz (all varieties) and rock crystal within Foz do Medal lithic assemblages: net amounts and percentages.

\begin{tabular}{|c|c|c|c|c|c|c|}
\hline & \multirow{2}{*}{$\begin{array}{l}\text { Total knapped stone } \\
\text { assemblage }(\mathrm{n})\end{array}$} & \multicolumn{2}{|c|}{ Quartz assemblage } & \multicolumn{3}{|c|}{ Rock crystal assemblage } \\
\hline & & $(\mathrm{n})$ & $(\%)$ & $(\mathrm{n})$ & $\begin{array}{l}\text { (\% within quartz } \\
\text { assemblage) }\end{array}$ & $\begin{array}{l}\text { (\% within knapped } \\
\text { stone assemblage) }\end{array}$ \\
\hline Early Mesolithic & 1079 & 987 & 91.5 & 99 & 10 & 9.2 \\
\hline Magdalenian & 159482 & 104670 & 65.6 & 1801 & 1.7 & 0.1 \\
\hline Solutrean & 782 & 339 & 43.4 & 32 & 9.4 & 4.1 \\
\hline Gravettian & 52071 & 43306 & 83.2 & 550 & 1.3 & 1.1 \\
\hline Early Upper Palaeolithic & 830 & 608 & 73.3 & 10 & 1.6 & 1.2 \\
\hline
\end{tabular}

The reduction sequences are not always complete in the lithic collections but it is possible to observe a local (or regional) preference for rocks with high silica content. The use of quartz and quartzite, which together comprises $81.4-96.6 \%$ of all knapped stone in Foz do Medal, are complemented with a large range of raw materials such as exogenous chert and regional fine-grained rocks rich in silica (jasper, lydite, hydrothermal silicifications and rhyolite). The diversification of raw material acquisition is an important characteristic of the prehistoric occupations of the Sabor valley.

The acquisition and management of raw material in Upper Paleolithic sites of Côa valley is somewhat diverse from the Sabor valley. At Côa valley the knapped stone assemblages have a stronger composition of quartz and quartzite (in all varieties) which can reach nearly 99\% of the assemblages (Aubry et al., 2004), and lack the greater variety in volcanic and metamorphic rocks fond at Sabor assemblages, probably due to the geological background. The Upper Paleolithic lithic collections studied in Côa valley are composed essentially of quartz, quartzite and a lower percentage of rock crystal and fine-grained quartz vein (Aubry et al., 2004). In the Gravettian assemblages of Cardina I, Insula and Olga Grande 4 percentages between $32.5 \%$ and $77.6 \%$ for quartz and between $9.9 \%$ and $19.7 \%$ for rock crystal were documented (Aubry, 2009). For the Magdalenian and Final Magdalenian assemblages of Fariseu and amount, especially in Solutrean, Magdalenian, and early Mesolithic phases. During the Solutrean the use of rock crystal for cores reached $62.5 \%$ indicating a clear preference for this raw material in relation with other quartz varieties. This can be explained by a desire of specific blank production, namely bladelets, small thin flakes and chips, although no bladelets were collected from the Solutrean levels.

The increasing preference for fine quartz varieties since the Gravettian is also observable in the tool assemblage (Fig. 7c). Concerning tool production, milky quartz was also an important choice, particularly regarding retouched flakes and denticulates. Since the Gravettian there is a clear decrease in quartz varieties with lesser knapping abilities.

Rock crystal has been considered a substitute for chert in regions where its acquisition costs are too high (Aubry et al., 2004). In the case of Foz do Medal, the use of rock crystal is especially relevant during Solutrean and in Early Mesolithic knapped stone assemblages. However, it was only during that last stage that the rock crystal was selected over chert (Table 2). A similar situation was also identified during the Mesolithic in Serra do Xistral in NW Iberia (Lombera Hermida and Rodríguez Rellán, 2010). During the Magdalenian rock crystal is only residual in Foz do Medal while on the other hand chert registers an increase in use.

Table 2

Relation between the use of rock crystal and chert in knapped stone assemblages from Foz do Medal during the different stages.

\begin{tabular}{|c|c|c|c|c|c|c|c|c|c|c|c|c|c|c|}
\hline & \multicolumn{4}{|c|}{ Knapped stone assemblage } & \multicolumn{5}{|c|}{ Core assemblage } & \multicolumn{5}{|c|}{ Tool assemblage } \\
\hline & \multicolumn{2}{|c|}{ Rock crystal } & \multicolumn{2}{|l|}{ Chert } & \multirow{2}{*}{$\frac{\text { Total }}{(\mathrm{n})}$} & \multicolumn{2}{|c|}{ Rock crystal } & \multicolumn{2}{|c|}{ Chert } & \multirow{2}{*}{$\frac{\text { Total }}{(\mathrm{n})}$} & \multicolumn{2}{|c|}{ Rock crystal } & \multicolumn{2}{|c|}{ Chert } \\
\hline & (n) & $(\%)$ & $(\mathrm{n})$ & $(\%)$ & & $(\mathrm{n})$ & $(\%)$ & $(\mathrm{n})$ & $(\%)$ & & (n) & $(\%)$ & (n) & $(\%)$ \\
\hline Early Mesolithic & 99 & 9.2 & 1 & 0.1 & 94 & 17 & 18.1 & 0 & 0 & 63 & 17 & 27 & 0 & 0 \\
\hline Magdalenian & 1801 & 1.1 & 9095 & 5.7 & 2357 & 220 & 9.3 & 285 & 12.1 & 2406 & 152 & 6.3 & 902 & 37.5 \\
\hline Solutrean & 32 & 4.1 & 74 & 9.5 & 63 & 10 & 15.9 & 6 & 9.5 & 61 & 5 & 8.2 & 17 & 27.9 \\
\hline Gravettian & 550 & 1.1 & 278 & 0.5 & 1135 & 46 & 4.1 & 10 & 0.9 & 380 & 44 & 11.6 & 31 & 8.2 \\
\hline Early Upper Palaeolithic & 10 & 1.2 & 19 & 2.3 & 28 & 1 & 3.6 & 0 & 0 & 23 & 1 & 4.3 & 0 & 0 \\
\hline
\end{tabular}

Quinta da Barca, the authors indicate percentages between $81.2 \%$ and $84.2 \%$ for quartz and between $0.6 \%$ and $3.9 \%$ for rock crystal (Aubry, 2009). The sources of these raw materials can be found within a few square kilometers.

In the lithic collections of Foz do Medal, we can see a large variety of quartz (Fig. 4). Its relative presence in knapped stone assemblages varies throughout the different stages of the site's occupation (Fig. 7). Concerning the knapped stone assemblage as a whole, we can observe that within the 7 types of quartz documented the most frequently used are milky quartz and the group of quartzes with less knapping ability (types i, j and k of Fig. 4). The quartz varieties with excellent knapping capacity (such as translucent quartz, fine-grained vein quartz, rock crystal, citrine and smoky quartz) are only present in a small percentage (Fig. 7a).

On the other hand, if we focus on the core assemblages (Fig. 7b) we can verify that these varieties (translucent quartz, rock crystal and smoky quartz) compose an important percentage of the total
Concerning only the core assemblage, there was a deliberate selection of rock crystal for blank production, especially since the Solutrean. Chert reaches relatively high percentages during the Solutrean and Magdalenian and is completely absent in early Upper Paleolithic and Early Mesolithic phases. Since biogenic chert is an exogenous raw material, thus with a high acquisition cost, it is possible that these values are underrepresented since the chert cores can be carried away with the human group. Regarding the tool assemblage, there is a clear preference for rock crystal in all phases, although during the Solutrean and Magdalenian the first choice is chert (Table 2). The high percentage of rock crystal cores during the Solutrean phase contrasts with the low proportion of this raw material in relation to chert among the tools. Only during the Gravettian does rock crystal surpasses chert.

It is likely that rock crystal blanks were used mostly unretouched, as barbs for projectile tips, as in the Gravettian assemblages of Côa valley (Klaric, 2009). 

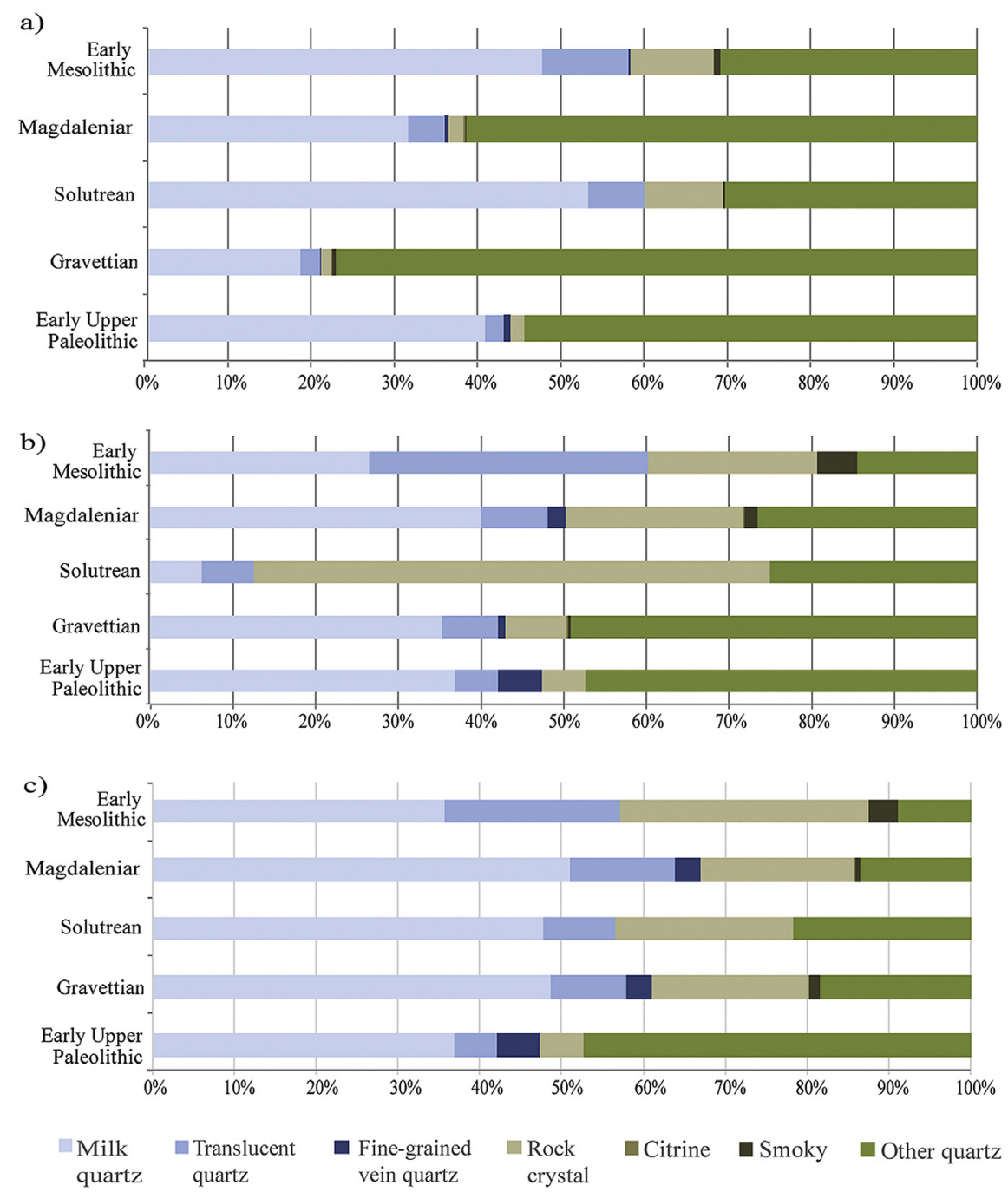

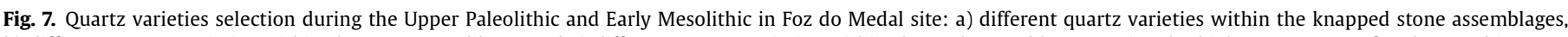

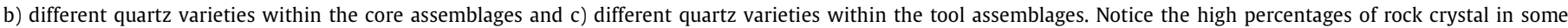
phases.

The relation with the Upper Paleolithic occupations of the nearby Côa valley is of the utmost importance on a regional level. In this sense, the Sabor valley becomes a counterpoint to the Côa valley, emphasizing the regional variety of subsistence strategies and technological choices, namely regarding the provision of raw materials. Chert is residual in Foz do Medal during the Gravettian, although it can reach $13.5 \%$ in Côa Valley (Aubry, 2009). In the case of rock crystal it is possible to observe presences between 9.9 and 19.7\% for the Côa Valley Gravettian (Aubry, 2009) while in Foz do Medal we observe no more than $1.1 \%$. Regarding the Magdalenian phase from Foz do Medal, the percentage of rock crystal in total knapped stone assemblage is only $0.1 \%$ while chert reaches $5.7 \%$, while in the Côa valley there is a preference for rock crystal over chert in Quinta da Barca and Fariseu (Aubry, 2009) though never surpassing $3.9 \%$ of the whole collection. Chert never surpasses $1.5 \%$ of the lithic assemblages in Côa valley.

Different reduction strategies were applied to the rock crystal prisms in order to obtain small flakes or bladelets. In the first phase of the Upper Paleolithic occupation, only one rock crystal core was identified, which was explored in a carinated "burin" manner. In this phase the use of rock crystal prisms has a small expression. This type of cores appear again only in the Magdalenian phase.
Among the strategies most frequently applied to the rock crystal prisms is the exploitation with a $45^{\circ}$ angle striking platform, using the crystals' natural edges as guides for the chipping, observable from the Gravettian to the Early Mesolithic. The presence of prismatic cores is also important although they are not present in the Solutrean phase. In this phase, we can only observe $45^{\circ}$ angle striking platform cores, splintered cores and cores with bifacial exploitation. The splintered cores present in all stages of the human occupation of the site, and as well as other exploited volumes, indicate that the bipolar on anvil knapping technique was used. In the Magdalenian phase one carinated "end-scraper" core was collected, being the only one made of rock crystal in the site. There is also one polyhedral core found in the Gravettian phase assemblage.

In the Upper Paleolithic assemblages of Foz do Medal it is possible to find rock crystals in their initial reduction phase, with just one or two removals. In the same way it is also frequent to find crystals in their raw morphology. Although we can find different strategies within rock crystal prisms reduction, it is clear that the $45^{\circ}$ angle striking platform cores have had an important role in bladelets, small flakes and chips production, especially during Gravettian and Early Mesolithic phases (Table 3). 
Table 3

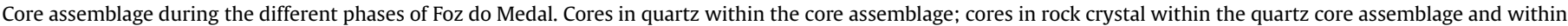
total core assemblage; $45^{\circ}$ angle striking platform on rock crystal cores within the rock crystal core assemblage and within the total core assemblage.

\begin{tabular}{|c|c|c|c|c|c|c|c|c|c|}
\hline & \multirow[t]{2}{*}{ Cores $(\mathrm{n})$} & \multicolumn{2}{|c|}{ Quartz cores } & \multicolumn{3}{|c|}{ Rock crystal cores } & \multicolumn{3}{|c|}{$45^{\circ}$ angle platform cores (rock crystal) } \\
\hline & & (n) & $\begin{array}{l}\text { (\% within } \\
\text { core assemb.) }\end{array}$ & (n) & $\begin{array}{l}\text { (\% within quartz } \\
\text { core assemb.) }\end{array}$ & $\begin{array}{l}\text { (\% within } \\
\text { core assemb.) }\end{array}$ & (n) & $\begin{array}{l}\text { (\% within RC } \\
\text { core assemb.) }\end{array}$ & $\begin{array}{l}\text { (\% within } \\
\text { core assemb.) }\end{array}$ \\
\hline Early Mesolithic & 94 & 83 & 88.3 & 17 & 20.5 & 18.1 & 13 & 76.5 & 13.8 \\
\hline Magdalenian & 2357 & 1026 & 43.5 & 220 & 21.4 & 9.33 & 54 & 24.5 & 2.3 \\
\hline Solutrean & 63 & 16 & 25.4 & 10 & 62.5 & 15.9 & 3 & 30 & 4.7 \\
\hline Gravettian & 1135 & 615 & 54.2 & 46 & 7.5 & 4.1 & 19 & 41.3 & 1.7 \\
\hline Early Upper Palaeolithic & 28 & 19 & 67.9 & 1 & 5.3 & 3.6 & 0 & 0 & 0 \\
\hline
\end{tabular}

\section{2. $45^{\circ}$ angle striking platform cores}

We have registered the presence of a specific reduction strategy applied to obtain rock crystal bladelets and small flakes. The rock crystal exploitation starts with the extraction of a small flake or bladelet near the extremity of the prism, which creates a $45^{\circ}$ angle between the striking platform and the debitage surface. Then the crystal's natural edges work as guides for the chipping, in similar way to crests.

The $45^{\circ}$ angle striking platform cores were primarily identified by Fabián García (1986) in La Dehesa (Salamanca, Spanish Meseta), but were then interpreted as tools - "Útiles de arista diédrica" (UAD). The chronology advanced by the author to the site was final Magdalenian or Epipaleolithic, based on stylistic characteristics of the lithic industry. Those type of cores were also identified in Mesolithic sites from the Alpes (Chelidonio, 1990) and later also registered in the older levels of Buraco da Pala rock shelter (Mirandela, Portugal), associated by Sanches (1997) to the Neolithic and in Neolithic settlements from Navarra region (Spain) (García Gazólaz and Velaz Ciáurriz, 1997). Recently, these pieces were studied from a technological perspective and reinterpreted as cores for bladelets and small flakes (Aubry et al., 2004; Gameiro, 2009; Klaric, 2009; Lombera Hermida et al., 2012).

It seems clear that this reduction strategy on rock crystal natural morphology was broadly applied in the northwestern part of Iberia during much of the Upper Paleolithic and continued in use throughout the Holocene. It was also one of the preferred methods for the production of blanks for lithic barbs during Sabor valley prehistoric occupations (Fig. 8) at least since the Gravettian (Table 4) as they are not present in the Early Upper Paleolithic phase. However, the small size of the Early Upper Paleolithic assemblage means that the absence of these cores during this stage should not be taken as definitive (Fig. 9).
The $45^{\circ}$ angle striking platform on rock crystal core total count in Foz do Medal is 82, although only 78 are analyzed here, since 4 of the objects ( 3 from Magdalenian phase and 1 from Gravettian phase) are doubtful and need revision.

This reduction strategy aimed the production of small sized bladelets (microbladelets), small flakes, and chips. Some of the cores present marks of anvil resting during knapping, but the majority should have been hand held. Core formatting was performed simply by creating a striking platform since the guide axis for the chipping was already accomplished by the crystal's morphology. Several cortical flakes showing the crystal natural edges were collected, while crest technique was never applied at the beginning of the reduction. Some cortical rock crystal flakes result from the creation of the $45^{\circ}$ angle striking platform since the crystal tip is visible on the dorsal side.

The striking platforms tend to be either flat or cortical, although a few cores present dihedral or facetted platforms. In the Gravettian phase, $57.9 \%$ of the $45^{\circ}$ angle striking platform cores present a flat platform and during the Magdalenian the proportion increases to $70.4 \%$. Conversely in the Solutrean assemblage only cores with cortical platforms were collected. During the Early Mesolithic, flat platforms are residual and the cortical platforms reach $40 \%$ of the total core collection.

Some of the cores present two striking platforms (on both ends of the rock crystal), usually exploring different debitage surfaces (alternating) in a sequential way, which means that the second surface is explored only after the first is exhausted. In some cases the $45^{\circ}$ angle exploitation is bifacial rather than unifacial, meaning that both surfaces are striking platforms and core fronts at a time.

Concerning the products obtained, we can observe that this strategy was applied mainly for bladelet production (Table 4), especially during the Solutrean where only one core was used for producing small flakes. However, very few rock crystal elongated blanks are present in the collections, in relation to the core number, and completely absent in the Solutrean levels (Fig. 7). This can be

Table 4

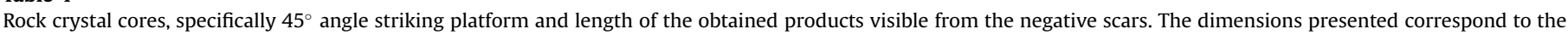
average length, at the abandonment stage.

Rock crystal $\quad 45^{\circ}$ platform on $45^{\circ}$ platform cores

cores $(\mathrm{n}) \quad$ rock crystal $(\mathrm{n}) \quad$ With negatives of bladelets

With negatives of flakes

(n) Core length Product

(mm) length ( $\mathrm{mm})$

\begin{tabular}{l}
\hline Early Mesolithic \\
Magdalenian \\
Solutrean \\
Gravettian \\
Early Upper \\
$\quad$ Palaeolithic \\
Total \\
\hline
\end{tabular}

17

220

10

10

46

$1 \quad 19$

294

5
54
4
19
0
82

$\begin{array}{rll}0 & - & - \\ 32 & 19 & 15 \\ 3 & 20 & 15 \\ 10 & 29 & 18 \\ 0 & - & - \\ 45 & - & -\end{array}$

\begin{tabular}{|c|c|c|c|c|c|}
\hline & \multicolumn{3}{|c|}{ bladelets and flakes } \\
\hline$(\mathrm{n})$ & $\begin{array}{l}\text { Core length } \\
(\mathrm{mm})\end{array}$ & $\begin{array}{l}\text { Product length } \\
(\mathrm{mm})\end{array}$ & $(\mathrm{n})$ & $\begin{array}{l}\text { Core length } \\
(\mathrm{mm})\end{array}$ & $\begin{array}{l}\text { Product length } \\
(\mathrm{mm})\end{array}$ \\
\hline 5 & 17 & 7 & 0 & - & - \\
\hline 13 & 21 & 12 & 6 & 21 & 13 \\
\hline 1 & 20 & 10 & 0 & - & - \\
\hline 3 & 23 & 14 & 5 & 25 & 12 \\
\hline 0 & - & - & 0 & - & - \\
\hline 22 & - & - & 11 & - & - \\
\hline
\end{tabular}



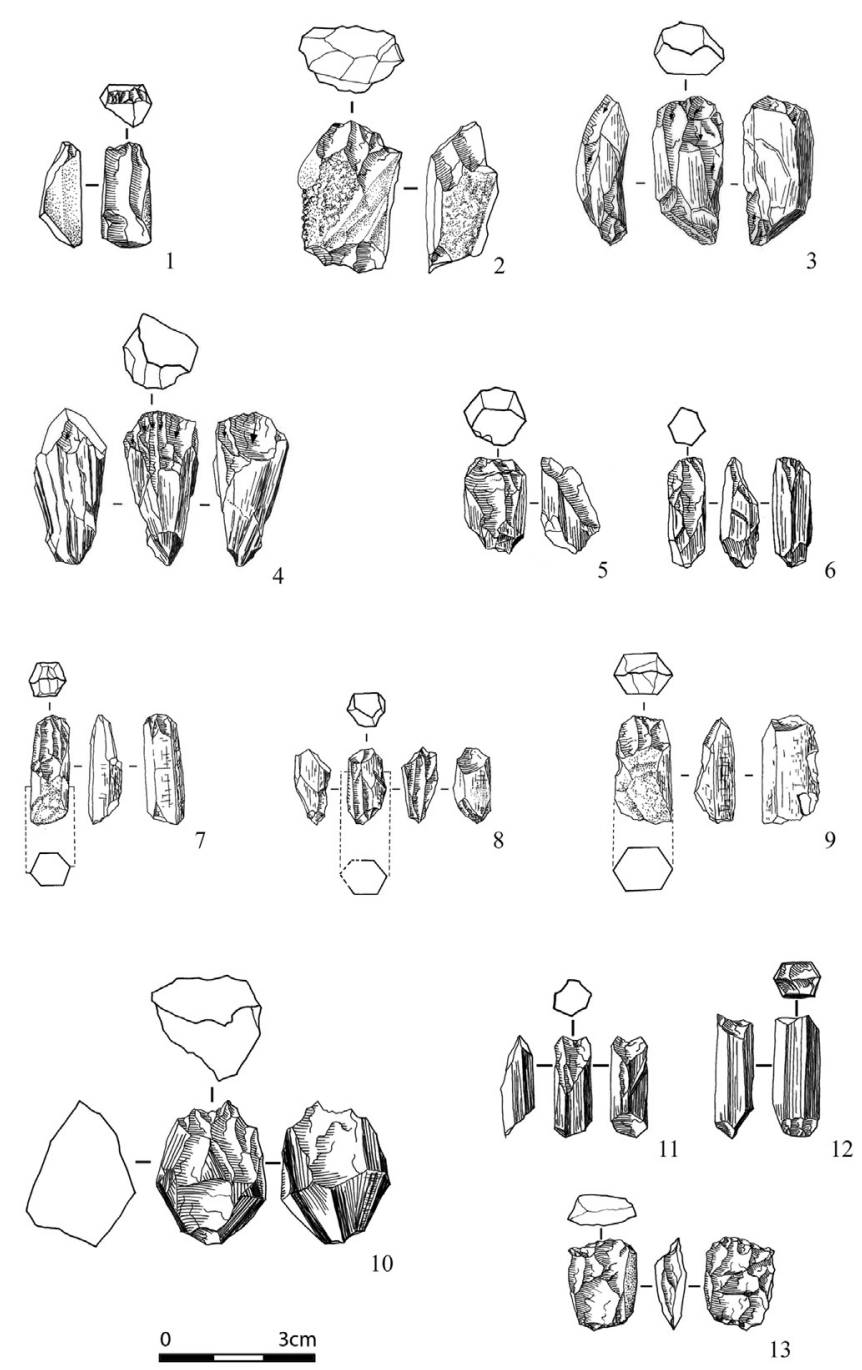

Fig. 8. Crystal rock cores from Foz do Medal site: 1, 2, 3 and 4 from the Gravettian level; 5 and 6 from the Solutrean occupation; 7, 8 and 9 from the Magdalenian level; 10, 11 and 12 from the Early Mesolithic levels and 13 splintered core from the Gravettian level (drawings by Maria Fernanda Sousa).

explained by a possible transport of a large number of those blanks from the site by the human group, which could then be used for repairing projectile tips in hunting activities. During the Gravettian and the Magdalenian, it is possible to observe that in some cores, both types of blanks, bladelets and small flakes, were intentionally obtained from the same core. Cores for "combined" blank production reach $11.1 \%$ in Madgalenian and $26.3 \%$ in the Gravettian. An important point to notice is the fact that during the Early Mesolithic phase this strategy was only used to obtain small flakes. The reduced size of the volumes does not exclude that at some point of the reduction cores could have been used for bladelet production. Technical issues or the maximization of raw material resources could have favored the production of chips and small flakes, which could have been also used as barbs, rather than bladelets.

The possible maximization of lithic resources can be seen when analyzing core dimensions (Fig.10). Regarding rock crystal core measures during Gravettian and Magdalenian phases we observe a maximum length of $47 \mathrm{~mm}$ and $36 \mathrm{~mm}$ respectively. The larger cores are linked to bladelet production. The negative extractions of bladelets vary from $30 \mathrm{~mm}$ to $7 \mathrm{~mm}$ in length. The blanks in both assemblages are coherent with the negative extractions present in the cores. The bladelets lengths from Gravettian phase range from $8 \mathrm{~mm}$ to $31 \mathrm{~mm}$ and between $8 \mathrm{~mm}$ and $28 \mathrm{~mm}$ in Magdalenian phase. At the same time, we found smaller cores in these collections measuring only $13 \mathrm{~mm}$ in length.

Regarding the small flakes or chips production, we find a major diachronic difference in size between Upper Paleolithic and Mesolithic assemblages. While in the Gravettian, Solutrean and Magdalenian the negatives of extractions have dimensions between 20 and $8 \mathrm{~mm}$, in the Early Mesolithic the removals have sizes between 9 and $7 \mathrm{~mm}$. Another important feature regarding these types of cores in the Early Mesolithic assemblage is their reuse as tools after exhaustion as cores. The creation of a notch at the edge of these cores (Fig. 6.8) is an important characteristic also present in other Sabor valley sites from this same chronology. It is clear that, as mentioned by Gameiro (2009: 268) regarding Côa valley lithic assemblages, these human populations clearly managed to maximize the local and regional lithic resources, which is well expressed in the bladelet production system from rock crystal volumes.

\section{Discussion and conclusions}

The raw material economy of human groups from inner regions of Northwestern Iberia is known to be quite different from the economy of groups from the Atlantic margin. In Northwestern Iberia, in which Sabor valley is included, due to the absence of sources of biogenic chert there is a preference for local raw materials for knapping activities, mainly quartz. Quartz is dominant in every lithic assemblage from Sabor valley. There is a large range of quartz varieties found in the collections with different knapping qualities and different availability, thus with distinct economies not only throughout the large chronological sequence but also within the same moments of occupation.

Foz do Medal offers the possibility to approach the raw material economy throughout the Upper Paleolithic sequence in the region. The predominance of quartz in the assemblages clearly declines during Solutrean, while quartzite and chert are the preferred raw materials. The use of quartz increased during the Magdalenian phase. At this stage we also observe an increasing use of local siliceous fine-grained rocks. It is only in the Early Mesolithic that quartz surpasses $90 \%$ of the assemblage. We observe a decrease in the use of quartz varieties with lesser knapping abilities since the Gravettian.

The variations in the frequency of raw materials during the different stages of Foz do Medal reflect the mobility patterns and human networks (Aubry et al., 2012), both regional and superregional, the lithic economy and the strategies applied in order to obtained the desired end-product, but at the same time the modern humans' increasing adaptation and knowledge of this territory and its resources. However, it is not easy to relate the use of fine quartz varieties, in opposition to raw material imports, to just one of these variables. Despite this, it is clear that at some stages (Magdalenian and Solutrean) the subsistence strategies demand for exotic raw materials whereas at other stages (Gravettian and Early Mesolithic) the local raw materials, especially quartz, seemed to have been the most economic choice. We did not observe a significant decrease in rock crystal use throughout the sequence, even during the Magdalenian, meaning that there was a continuous specialization in the exploitation of this regional resource.

Within the several assemblages it is possible to observe that the best quality quartzes, like some milky quartz, fine-grained vein quartz, translucent quartz, smoky quartz and rock crystal, were mostly selected to produce bladelets and small flake to use as blanks for retouched lithic barbs, as is the case of the microgravette in rock crystal, or non-retouched ones. These varieties are also 
Flakes

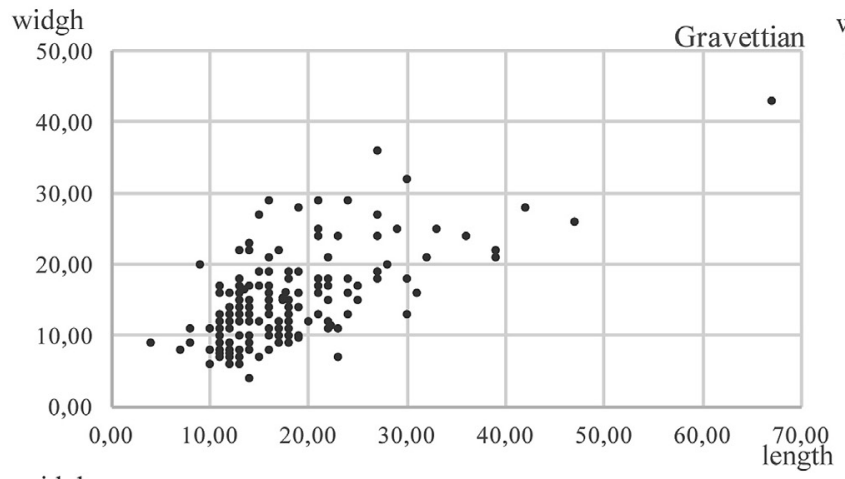

Elongated blanks

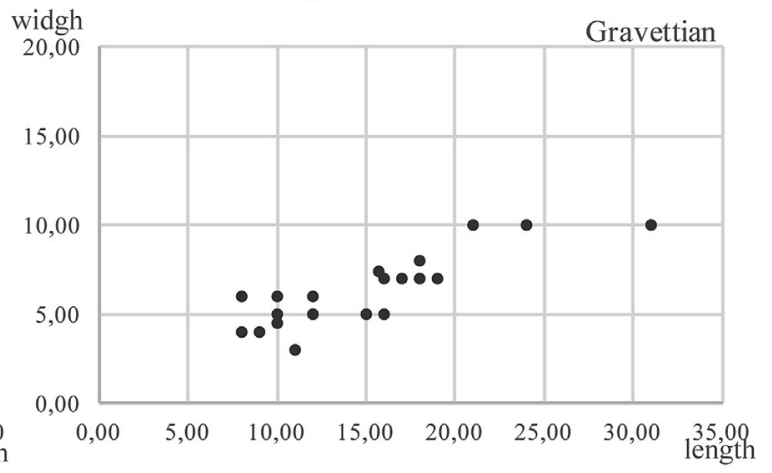

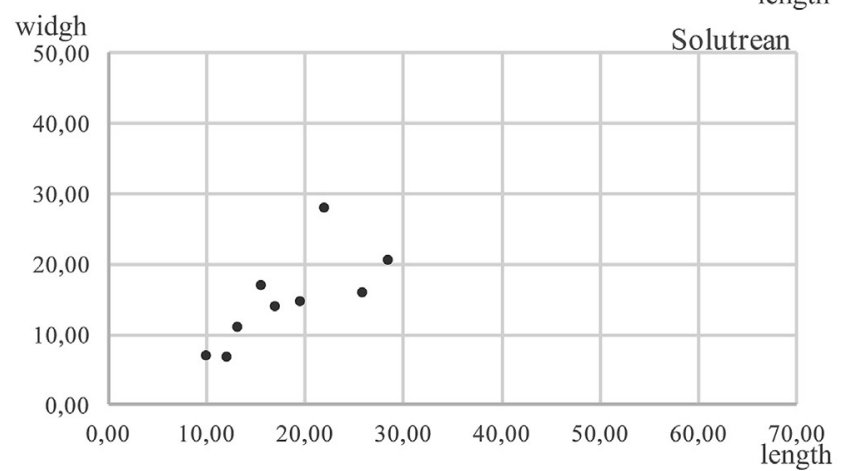
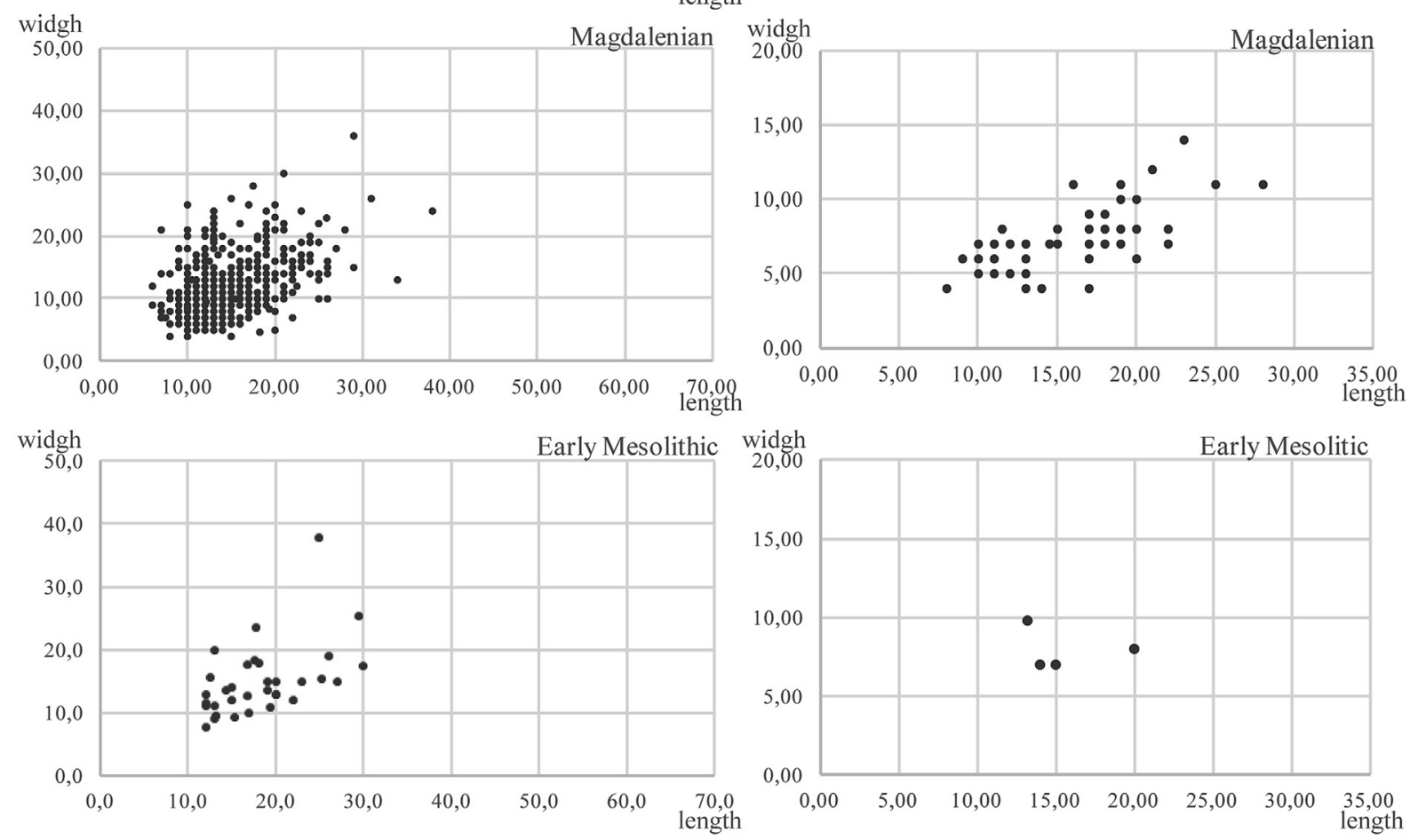

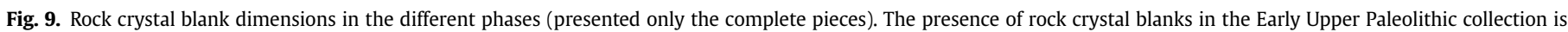
residual, therefore no graphic representation was made. Notice the absence of bladelets in the Solutrean assemblage.

selected to produce high-end tools such as the case of the laurel leaf in milky quartz presented on Fig. 6. The laurel leaf is a paradigmatic example since these points are almost exclusively produced in flint, even in the nearby Côa valley sites (Aubry, 2009). Quartz is clearly not a marginal raw material and human groups that inhabited this territory were able to maximize this local lithic resource. A good example is the rock crystal economy and its use as a valuable alternative to chert, or, in some cases, its use in a complementary way to chert and others siliceous fine-grained regional rocks, namely concerning tool and weapon production.

The use of rock crystal seems to have a fundamental role in the Upper Paleolithic and Early Mesolithic industries since even in the presence of sources of other siliceous fine-grained rocks, with similar acquisition costs, rock crystal was still broadly used. Human groups selected fine quartz varieties over those raw materials (nonlocal cherts and other regional siliceous fine-grained rocks) which 

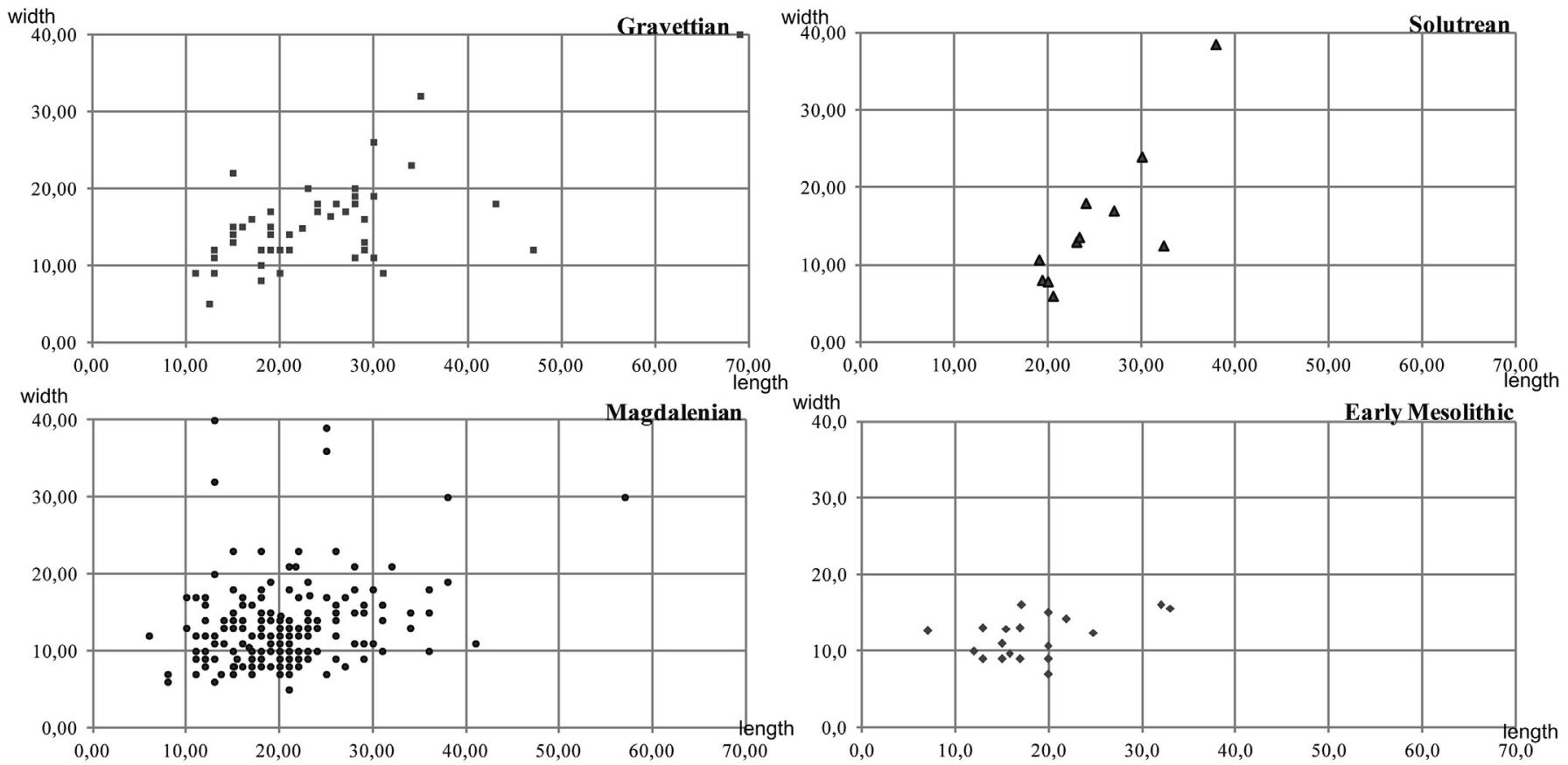

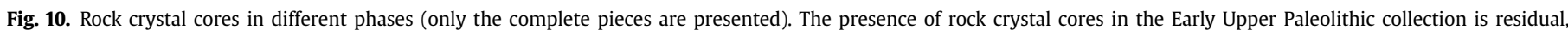
therefore no graphic representation was made.

also present good knapping qualities. A possible explanation for this is the fact that there are some advantages in the use of rock crystal since it allows an intensive exploitation of the cores, even below $1 \mathrm{~cm}$ size (Aubry and Araúijo Igreja, 2009). The selection of rock crystal seems to have been especially relevant during the Solutrean and the Early Mesolithic phases.

Despite being present in almost all phases of Foz do Medal, they show some variability throughout the chronological sequence. Several reduction strategies are applied to the rock crystal volumes in order to obtain either small flakes or bladelets. In case of the $45^{\circ}$ angle, striking platform cores they are completely absent in the Early Upper Paleolithic phase and gained great importance in the Early Mesolithic phase.

\section{Acknowledgements}

We would like to thank EDP-Produção, sponsor of Aproveitamento Hidroelétrico do Baixo Sabor (Baixo Sabor dam), and Baixo Sabor, ACE (ODEBRECHT/Bento Pedroso Construções S.A e LENA, Construções), executers of the construction project. We would like to express our recognition to the prehistoric team without whom the inventory of the collections would be impossible and to geologist José Feliciano who identified some of the raw material categories. We thank also to the archaeology firms that work with us during the field work, Neoépica - Arqueologia e Património, Lda, Archeoestudos, Lda. and Arqueologia e Património Lda. A final word for the other colleagues involved in Plano da Salvaguarda do Património (PSP) coordination: J. Sastre, S. Pereira, L. Fontes, F. Santos, P. Dordio, S. Figueiredo, S. Antunes and S. Lainho. We would like to thank João Tereso for the major revisions concerning English grammar and spelling. Finally we would like to express our gratitude to the reviewers whose suggestions greatly improved this paper.

\section{References}

Alday, A., 2006. El Mesolítico de muescas y denticulados en la cuenca del Ebro y el litoral mediterráneo peninsular: sínteses de los datos. In: Alday, A. (Ed.), El mesolítico de muescas y denticulados en la cuenca del Ebro y el litoral mediterráneo peninsular. Diputacíon Foral de Alava, Departamento de Cultura, pp. 303-317.

Almeida, F., 2000. The Terminal Gravettian of Portuguese Estremadura (Ph.D. Dissertation). Southern Methodist University.

Aubry, T. (Ed.), 2009. 200 séculos da História do vale do Côa: incursões na vida quotidiana dos caçadores-artistas do Paleolítico. Igespar, Lisbon.

Aubry, T., Araújo Igreja, M., 2009. Economy of lithic raw material during the Upper Paleolithic of the Côa valley an the Sicó massif (Portugal): technological and functional perspectives. In: Proceedings of the Functional Studies of Non Flint Stone Tools: Methodological Improvements and Archaeological Inferences. Lisbon, 23-25 May 2008.

Aubry, T., Mangado, J., 2006. The Côa Valley (Portugal). Lithic raw material characterization and the reconstruction of Upper Palaeolithic settlement patterns. In: Bressy, C., Burke, A., Chalard, P., Martin, H. (Eds.), Notions de territoire et de mobilité. Exemples de l'Europe et des premières nations en Amérique du Nord avant le contact européen. Actes de sessions presentées au Xe congrés annuel de l'Association Européene des Archéologues (EAA), Lyon, 8-11 septiembre 2004, Liége, ERAUL, 116, pp. 41-49.

Aubry, T., Luís, L., Mangado Llach, X., Matias, H., 2012. We will be known by the tracks we leave behind: exotic lithic raw materials, mobility and social networking among the Côa Valley foragers (Portugal). Journal of Anthropological Archaeology 31 (4), 528-550.

Aubry, T., Mangado, J., Fullola, J.M., Rosell, L., Sampaio, J.D., 2004. The raw material procurement at the Upper Palaeolithic settlements of the Côa valley (Portugal): new data concerning modes of resource exploitation in Iberia. In: The Use of Living Space in Prehistory. BAR series, pp. 37-50.

Aubry, T., Mangado Llach, J., Matias, H., 2014. Matérias-primas das ferramentas em pedra lascada da Pré-história do Centro e Nordeste de Portugal. In: Dinis, P.A., Gomes, A., Monteiro-Rodrigues, S. (Eds.), Proveniências de Materiais Geológicos: abordagens sobre o Quaternário de Portugal. APEQ, pp. 165-192.

Bracco, J.-P., 1998. Le debitage du quartz dans le Paleolithique superieur d'Europe Occidentale: aspects technologiques et comportementaux. Lithic technology. From raw material procurement to tool production. In: Proceedings of the Workshop $\mathrm{n}^{\circ} 12$, of the XIII International Congress of Prehistoric and Protohistoric Sciences, Forlì, 8-14 September 1996. Universitá degly studi di Ferrara, pp. 81-90.

Cabral, J., 1995. Neotectónica em Portugal Continental. Instituto Geológico e Mineiro, Lisboa.

Chelidonio, G., 1990. Preliminary approach to quartz crystals technology and its meaning as "Environmental Translation". In: Séronie-Vivien, M.R., Lenoir, M. (Eds.), Le Silex de sa genèse à loutil. Actes du $\mathrm{V}^{\circ}$ Colloque international sur le Sílex. Cahiers du Quaternaire, 17, pp. 489-494.

Driscoll, K., 2011. Vein quartz in lithic traditions: an analysis based on experimenta archaeology. Journal of Archaeological Science 38, 734-745.

Fabián García, J.F., 1986. La industria lítica del yacimiento de la Dehesa en El Tejado de Béjar (Salamanca). Una indústria de tipologia magdalenense en la Meseta. Numantia 2, pp. 101-143. 
Figueiredo, S.S., Nobre, L., Gaspar, R., Carrondo, J., Cristo-Ropero, A., Ferreira, J., Silva, M.J., Molina, F.J., 2014. Foz do Medal terrace. An Open-air Settlement with Paleolithic Mobile Art. INORA - International Newsletter on Rock Art 68, pp. $12-20$.

Figueiredo, S.S., Xavier, P., Nobre, L., 2015. Placas móveis com grafismos rupestres paleolíticos do Terraço do Medal (Nordeste, Portugal): uma primeira análise a temas e estilos). Arkeos 37, 1573-1588.

Gameiro, C., 2009. Utensílios e suportes microlíticos do Magdalenense Final no Vale do Côa: o exemplo da U.E. 4 do Fariseu. In: Aubry, T. (Ed.), 200 séculos da história do Vale do Côa: incursões na vida quotidiana dos caçadores-artistas do Paleolítico. Trabalhos de Arqueologia 52. Igespar, Lisboa, pp. 256-268.

Gaspar, R., Carrondo, J., Nobre, L., Rodrigues, Z., Donoso, G., 2014. Espaço para a morte. O terraço da Foz do Medal (Vale do Sabor, Nordeste de Portugal) durante a Idade do Bronze. Estudos do Quaternário 10, 59-72.

Gaspar, R., Ferreira, J., Carrondo, J., Silva, M. J., García-Vadillo, F. J, (accepted a). Open-air Gravettian lithic assemblages from Northeast Portugal. The Foz do Medal site (Sabor valley). Quaternary International.

Gaspar, R., Ferreira, J., Molina Hernández, F., García-Vadillo, F.J., Rebelo, P., Neto, N., (accepted b). Away from the edges: a new Solutrean site in interior Iberia. Foz do Medal Left Bank, Sabor Valley, Northeast Portugal (NW Iberia). Journal of Anthropological Research, 71-74.

Gaspar, R., Pedro, J., Mata, J., 2009. Estudo arqueopetrográfico da utensilagem lítica do sítio neolítico da Lajinha 8 (Évora). Revista Portuguesa de Arqueologia 12-1, 19-33.

García Gazólaz, J., Velaz Ciáurriz, D., 1997. La industria lítica tallada de las primeras comunidades neolíticas en la cuenca de Pamplona (Navarra): El caso del cristal de roca. Cuadernos de Arqueología 5, 7-29.

Klaric, L., 2009. Les systèmes de production de supports d'armatures et leur place dans la gestion des ressources lithiques: une voie privilégiée pour la comprehension des societies gravettiennes de la Vallé du Côa. In: Aubry, T. (Ed.), 200 séculos da história do Vale do Côa: incursões na vida quotidiana dos caçadoresartistas do Paleolítico. Trabalhos de Arqueologia 52. Igespar, Lisboa, pp. 247-256.

Klaric, L., Guillermin, P. Aubry, T., 2009. Des Armatures variées et des Modes de Productions variables: Réflexions à partir de quelques exemples issus du
Gravettien d'Europe occidentale (France, Portugal, Allemagne). Gallia Préhistoire 51, 113-154.

Lombera Hermida, A., Rodríguez Rellán, C., 2010. Gestión y estrategias de abastecimiento de las materias primas locales (cuarzo, cuarcita y pizarra) en la Prehistoria del NW Peninsular. In: Dominguez-Bella, S., Ramos Muñoz, J., Gutiérres López, J.M., Pérez Rodríguez, M. (Eds.), Minerales y rocas en las sociedades en la prehistoria. Universidad de Cádiz, pp. 49-60.

Lombera Hermida, A., Rodríguez Álvarez, X.-P., Rabuñal Gayo, X., Ameijenda Iglesias, A., Martínez Gómez, F., Soares Remiseiro, M., Pérez Alberti, A., Fábregas Valcarce, R., 2012. El yacimiento de Valverde (Monforte de Lemos, Lugo, Galicia, España) y las primeras evidencias de poblamiento en el Pleniglacial del No de la Península Ibérica. Espacio, Tiempo y Forma Serie I, Nueva época Prehistoria y Arqueología 5, 363-382.

Perea, H., Cabral, J., Marques Figueiredo, P., Besana-Ostman, G.M., Silveira, A.B., Cunha, P.P., Gomes, A., Lopes, F.C., Pereira, D., Rockwell, T., 2010. Actividade sísmica quaternária da falha da Vilariça (NE Portugal): resultados preliminares de um estudo paleossismológico. E-Terra - Revista Electrónica de Ciências da Terra 11 (6), 1-4.

Rockwell, T., Fonseca, J., Madden, C., Dawson, T., Owen, L.A., Vilanova, S., Figueiredo, P., 2009. Paleoseismology of the Vilariça Segment of the ManteigasBragança Fault in Northeastern Portugal, 316. Geological Society London Special Publication, pp. 237-258.

Sanches, M.J., 1997. e 2. In: Pré-história Recente de Trás-os-Montes e Alto Douro (o abrigo do Buraco da Pala no Contexto Regional), vol. 1. Sociedade Portuguesa de Antropologia e Etnologia, Porto.

Silva, A.F., Rebelo, J.A., Ribeiro, M.L., 1989. Notícia explicativa da Folha 11C - Torre de Moncorvo. Serviços Geológicos de Portugal, Lisboa.

Tallavaara, M., Manninen, M., Hertell, E., Rankama, T., 2010. How flakes shatter: a critical evaluation of quartz fracture analysis. Journal of Archaeological Science 37, 2442-2448.

Zilhão, J., 1997. O Paleolítico Superior na Estremadura Portuguesa. Edições Colibri, Lisbon.

Zilhão, J., Aubry, T., Almeida, F., 1997. L'utilisation du quartz pendant la transition Gravettien-Solutréen au Portugal. Préhistoire Anthropologie Mediterranéennes $6,289-303$. 